\title{
TÜRKIYE'DEKI ÜNIVERSITELERDE TMS/TFRS EĞiTiMI ÜZERINE BIR ARAŞTIRMA
}

\author{
Mustafa KILLI*
}

\begin{abstract}
$\ddot{\mathbf{O z}}$
Dünya ekonomisinde ve rekabet şartlarında yaşanan değişmeler finansal tablo kullanıcılarının nitelikli bilgiye olan gereksinimini artmıştır. Bu gereksinimin karşılanabilmesi için, muhasebe ve finansal raporlama uygulamalarında ortak bir dilin kullanılması gerekli hale gelmiştir. Bu gerekliliğin bir sonucu olarak Uluslararası Muhasebe/Finansal Raporlama Standartları yayınlanmıştır. Dünyada yaşanan bu gelişmeler ülkemizde de yakından izlenmiş ve Türkiye Muhasebe/Finansal Raporlama Standartları (TMS/TFRS) yayınlanmıştır. Standartların yayınlanması, muhasebe ve finansal raporlama uygulamalarına birçok farklılık ve yenilik getirmiştir. Bu çalışmada, Türkiye'deki devlet ve vakıf üniversitelerinin muhasebe eğitimi verilen lisans ve lisansüstü programlarında muhasebe ve finansal raporlama standartlarına ilişkin derslerin verilme düzeyi araştırılmıştır. Araştırma sonuçları, Türkiye'deki, üniversitelerin muhasebe eğitimi verilen lisans, yüksek lisans ve doktora programlarında TMS/TFRS eğitimine gereken önemin henüz verilmediğini göstermektedir.
\end{abstract}

Anahtar Kavramlar: Muhasebe Standartları, Finansal Raporlama Standartları, Muhasebe Eğitimi, Türkiye'deki Üniversiteler.

\section{A RESEARCH ON TMS/TFRS EDUCATION IN THE UNIVERSITIES IN TURKEY}

\begin{abstract}
Changes in the world economy and competitive conditions, the financial statement users' has increased the need for qualified information. In order to meet the needs has become necessary to use a common language. As a result of this requirement, International Accounting/Financial Reporting Standards have been published. This developments taking place in the world was followed closely in our country and Turkey Accounting / Financial Reporting Standards (TAS/TFRS) have been published. The publication of the standards has brought many differences and innovation to accounting and financial reporting practices. In this study, it's aimed to investigate given level of courses related accounting and financial reporting standards in the undergraduate and graduate accounting education programs of the state and private universities in Turkey. Results of research Show that TAS/TFRS are not given the importance to in the undergraduate, graduate and docrtoral programs at the universities in Turkey.
\end{abstract}

Keywords: Accounting Standarts, Financial Reporting Standarts, Accounting Education, Universities in Turkey.

\footnotetext{
* Dr. Öğr. Üyesi, Osmaniye Korkut Ata Üniversitesi, İktisadi ve İdari Bilimler Fakültesi, Uluslararası Ticaret ve Lojistik Bölümü.

Makalenin kabul tarihi: Temmuz 2017.
} 


\section{GİRIŞ}

Yatırımcıların küresel bir boyut kazanan sermaye piyasalarında yatırım kararı alabilmeleri, söz konusu yatırıma konu olacak şirketler hakkındaki finansal bilgilerin doğru, güvenilir ve anlaşılabilir bir şekilde elde edilebilmesi ihtiyacını ortaya çıkarmıştır. Finansal bilgilere duyulan bu ihtiyaç dünya genelinde muhasebe uygulamalarının uyumlaştırılmasını zorunlu hale getirmiştir. Muhasebe uygulamaları açısından dünyada en çok bilinen iki muhasebe standardı setinden birincisi US GAAP (United States General Accepted Accounting Principles), ikincisi ise Uluslararas1 Finansal Raporlama Standartlar1 (UFRS/IFRS: International Financal Reporting Standarts)'dır (İbiş, Özkan, 2006: 30). Uluslararası Muhasebe Standartlar1 Komitesi (IASC-International Accounting Standarts Committee) tarafindan oluşturulan UFRS'ler ilke bazlı standartlar iken Amerikan Finansal Muhasebe Standartlar1 Kurulu (FASB-Financial Accounting Standart Board) tarafindan oluşturulan US GAAP standartlarının kural bazlı olması bu iki standart seti arasındaki temel farkl11ıktır (Agoglia vd., 2011: 749). Kural bazlı standartların karmaşı olması, manipüle edilebilmesi nedeniyle finansal raporların kalitesinin büyük ölçüde kaybolduğu, ilke bazlı standartların ise kural bazlı standartlara oranla daha kaliteli finansal raporlar sunulmasını sağladığı kabul edilmektedir (Akgün, 2012: 8).

Bu çalışmada öncelikle dünyada ve Türkiye'de muhasebe standartlarının oluşturulma süreci ve muhasebe standartlarının muhasebe eğitimine etkileri anlatıldıktan sonra üniversitelerimizde lisans ve lisansüstü düzeyde muhasebe standartlarına ilişkin derslerin verilme durumu incelenmiştir.

\section{DÜNYADA VE TÜRKIYYE'DE MUHASEBE STANDARTLARININ OLUŞTURULMA SÜRECI}

\section{A. ULUSLARARASI MUHASEBE STANDARTLARI}

Gelişmekte olan ülkelerin ekonomik kalkınmalarını gerçekleştirirken karş1laştıkları en önemli sorun sermaye yetersizliğidir (Takım, 2010:40). Gelişmekte olan ülkeler yabancı sermaye girişini sağlayacak uygulamalar ile bu sorunu çözmeye çalışırlar. Yabancı yatırım ve sermaye girişinin sağlanabilmesi için kaliteli finansal bilgiye olan ihtiyaç öne çıkmaktadır. Kaliteli finansal bilgi üretimi ülkelerin muhasebe sistemleriyle ilişkili olduğundan yabancı yatırımcıların sermaye piyasalarında yatırım yapabilmeleri için muhasebe alanında ortak bir dilin kullanılması gerekmektedir. Bu ihtiyacın karşılanabilmesi için uluslararası muhasebede iki önemli kavram olan "standartlaştırma" ve "uyumlaştırma" kavramları ön plana çıkmıştır (Kıymetli Şen vd., 2016: 26).

Uluslararas1 Muhasebe Standartları Komitesi (IASC) muhasebe standartlar1nın uluslararası düzeyde uyumlaştırılmasına yönelik çalışma yapan kuruluşların başında gelmektedir. IASC, 1973 yılında Avustralya, Kanada, Fransa, Japonya, Meksika, Hollanda, İngiltere, Amerika Birleşik Devletleri ve Almanya'nın aralarında bulunduğu dokuz ülkenin muhasebe kurulları tarafindan kurulmuştur (Nobes, Parker, 2008: 79). Komite, denetlenmiş hesapların ve finansal raporların sunulmasında dikkate alınması gereken temel standartları belirleyip, bunları kamuya açık bir şekilde yayınlamak ve böylece bu hesapların dünya genelinde kabul 
edilme ve dikkate alınma olanağını arttırmak temel amacı ile kurulmuştur (Gökçen vd., 2011:15).

Komite tarafindan 41 tane standart yayınlanmış olup bunlardan 31 tanesi halen yürürlüktedir. Uluslararası Muhasebe Standartlar1 Komitesi (IASC), 2001 y1lında Uluslararası Muhasebe Standartları Kurulu (IASB-International Accounting Standarts Board) olarak yeniden yapılandırılmıştır. IASB muhasebe standartlarını geliştirmeye devam etmiş ve oluşturduğu yeni standartları IFRS (International Financial Reporting Standarts) olarak yayımlamıştır. IASB tarafından yayınlanan düzenlemeler uygulayıcılar açısından uyulması gereken hususları düzenlemektedir (Durak, 2012: 39). IASB tarafindan yayınlanan bu düzenlemeler; Uluslararası Muhasebe Standartları (UMS, 2001 öncesi yayımlanan standartlar), Uluslararası Finansal Raporlama Standartları (UFRS, 2001 sonras1 yayımlanan standartlar), Finansal Raporlama Kavramsal Çerçevesi ve Uluslararası Finansal Raporlama Yorumları olmak üzere 4 ayrı başlık altında toplanmaktadır.

\section{B. TÜRKIYYE MUHASEBE STANDARTLARI}

Muhasebe standartlarının oluşturulmasına yönelik olarak ülkemizde yapılan çalışmalar incelendiğinde, bu çalışmaların tarihsel süreç içinde çeşitli kuruluşlar tarafindan üstlenildiği görülmektedir. Sermaye Piyasası Kurulu, Maliye Bakanlığı koordinatörlüğünde kurulan Muhasebe Standartları Komisyonu, Türkiye Muhasebe ve Denetim Standartları Kurulu (TMUDESK), Türkiye Muhasebe Standartları Kurulu (TMSK) bu kuruluşlar arasında sayılmaktadır (Başpınar, 2004: 4649). TMUDESK ve TMSK standartların hazırlanmasında görev alan iki önemli kuruluştur. Türkiye Serbest Muhasebeci, Mali Müşavirler ve Yeminli Mali Müşavirler Odaları Birliği (TÜRMOB) tarafından 9 Şubat 1994 tarihinde kurulan TMUDESK'in kuruluş amacı, denetlenmiş finansal tabloların sunumunda ihtiyaca uygun, gerçek, güvenilir, dengeli, karşılaştırılabilir ve anlaşılabilir nitelikte olmaları için ulusal muhasebe ilkelerinin gelişmesi ve benimsenmesini sağlayacak ve kamu yararı için uygulanacak ulusal muhasebe standartları ile muhasebe meslek mensuplarının, denetim faaliyetlerini yürütebilmeleri için ulusal denetim standartlarını saptamak ve yayınlamaktır (Gökçen vd., 2011: 9). Bu amaç ve esaslar doğrultusunda TMUDESK tarafindan yapılan çalışmalar sonucu 19 adet muhasebe standardı yayınlanmıştır. TMUDESK tarafından oluşturulan bu standartlar herhangi bir yasal düzenleme kapsamında olmadığından yaptırım gücü olmamıştır (Gücenme, Gençoğlu, 2007:5). Sermaye Piyasası Kanunu'nda değişiklik yapan 18 Aralık 1999 tarih ve 4487 sayılı kanunla ulusal muhasebe standartlarını saptamak ve yayımlamak üzere TMSK kurulmuş ve TMUDESK' in yetkileri TMSK'ya devredilmiştir. TMUDESK tarafindan yayınlanan 19 adet standart TMSK tarafindan yapılan çalışmalara önemli bir alt yapı sağlamıştır.

TMSK'nın yayımladığı muhasebe standartları, finansal raporlama standartları ve yorumlar Türkiye Muhasebe Standartları Setini oluşturmaktadır. Bu standartlar da zaten IASB'nın yayımlamış olduğu UMS, UFRS ve Uluslararası Finansal Raporlama Standartları Yorumları'nın (IFRIC) birebir Türkçeye çevrilmiş halidir. TMSK, IASB'nin yayımlamış olduğu UMS/UFRS setini aynen uygulama konusunda ilke kararı almış ve IASB ile yaptı̆̆ telif hakkı sözleşmesi kapsamında UMS/UFRS'lerin Türkçe çevirilerini Türk Muhasebe Standartları (TMS)/Türkiye 
Finansal Raporlama Standartları (TFRS) adı altında resmi gazetede yayımlamıştır (Akdoğan, 2007: 102).

TMSK'nın görev ve yetkileri, 2 Kasım 2011 tarihli resmi gazetede yayınlanarak yürürlüğe giren 660 sayılı Kanun Hükmünde Kararname ile Kamu Gözetimi, Muhasebe ve Denetim Standartları Kurumuna (KGK) geçmiştir. KGK'nın temel amacı, yatırımcıların çıkarlarını ve denetim raporlarının doğru ve bağımsız olarak hazırlanmasına ilişkin kamu yararını korumak, doğru, güvenilir ve karşılaştırılabilir finansal bilginin sunumunu sağlamaktır (KGK, 2016).

Menkul kıymetleri sermaye piyasalarında halka arz edilmiş işletmeler ile bu işletmelerin finansal tablolarının kullanıcılarının ihtiyaçlarına cevap vermek için hazırlanmış olan ve Tam Set UFRS olarak isimlendirilen standartların kapsamı oldukça geniş tutulmuştur (Hacıhasanoğlu vd., 2012: 166). Bu nedenle UMSK tarafindan 2009 yılında KOBI'ler için Uluslararası Finansal Raporlama Standartları (SME's IFRS) yayınlanmıştır. UMSK tarafından yayınlanan bu standartlar TMSK tarafindan çevirisi yapılarak 01.11.2010 tarihinde Resmi Gazetede yayınlanıp "KOBİ'ler için TFRS" adı altında yürürlüğe girmiştir. Uygulanacak standartların kapsamına bağlı olarak, KOBI'ler kamuya hesap verme yükümlülüğü bulunmayan ve dış kullanıcılar için genel amaçlı finansal tablo yayımlayan işletmeler olarak tanımlanmışlardır.

\section{TMS'NIN UYGULAMA KAPSAMI}

TMS'yi zorunlu olarak uygulayacak olan işletmelere 6102 sayılı Türk Ticaret Kanunu'nda yer verilmiş ve ayrıca KGK'ya uygulamadan muaf olacak kurum ve kuruluşları tespit etmek veya bunlar için ayrı düzenlemeler yapmak yetkisi verilmiştir. Bu kapsamda KGK tarafından 26/08/2014 tarihli "Türkiye Muhasebe Standartlarının Uygulama Kapsamının Belirlenmesine İlişkin Kurul Kararı'nın Resmi Gazete'de yayımlanması ile TMS'leri uygulayacak işletmeler belirlenmiştir. TMS Uygulama Kapsamına İlişkin Kurul Kararına ekli listedeki kurum, kuruluş ve işletmelerin 01/01/2014 tarihi ve sonrasında başlayan hesap dönemlerine ait münferit veya konsolide finansal tabloların hazırlamasında TMS'yi uygulamasına karar verilmiştir. Buna göre ekli listede yer alan kurum, kuruluş ve işletmeler aşağıda verilmiştir.

1) 6362 say1lı Sermaye Piyasas1 Kanunu uyarınca Sermaye Piyasas1 Kurulunun düzenleme ve denetimine tabi işletmelerden; a) Sermaye piyasası araçları bir borsada işlem gören anonim şirketler, b) Yatırım kuruluşları, c)Kolektif yatırım kuruluşları, d) Portföy yönetim şirketleri, e) İpotek finansmanı kuruluşları, f)Konut finansmanı ve varlık finansmanı fonları, g) Varlık kiralama şirketleri, h)Merkezî takas kuruluşları, i) Merkezî saklama kuruluşları, j)Veri depolama kuruluşları, k) Sermaye piyasası araçları bir borsada işlem görmeyen ancak Sermaye Piyasası Kanunu kapsamında halka açık sayılan şirketlerden: Aktif toplamı 15 milyon TL ve üstü, Yıllık net satış hasılatı 20 milyon TL ve üstü ve Çalışan sayısı 50 ve üstü olmak şartından en az ikisini sağlayanlar: 
2) 5411 sayılı Bankacılık Kanunu uyarınca Bankacılık Düzenleme ve Denetleme Kurumunun (BDDK) düzenleme ve denetimine tabi işletmelerden; a) Bankalar, b) Finansal kiralama şirketleri, c) Faktöring şirketleri, d) Finansman şirketleri, e) Varlık yönetim şirketleri, f) Derecelendirme kuruluşları, g) Finansal holding şirketleri, h) Finansal holding şirketleri üzerinde 5411 sayılı Kanunda tanımlandığı şekliyle nitelikli paya sahip olan şirketler, i) Ödeme kuruluşları ve elektronik para kuruluşları.

3) 5684 sayılı Sigortacılık Kanunu ve 4632 sayılı Bireysel Emeklilik Tasarruf ve Yatırım Sistemi Kanunu kapsamında faaliyet göstermekte olan sigorta, reasürans ve emeklilik şirketleri.

4) Borsa İstanbul Piyasalarında faaliyet göstermesine izin verilen; yetkili müesseseler, kıymetli madenler aracı kurumları, kıymetli maden üretimi veya ticareti ile iştigal eden anonim şirketler.

KGK'nın ilgili kararına göre, ekli listede yer almayan kurum, kuruluş ve işletmelerin de finansal tablolarını hazırlarken isteğe bağlı olarak TMS'yi uygulayabileceği belirtilmektedir.

KGK'nın bu kararından önce TMS'nin uygulama kapsamı, bağımsız denetimin kapsamına eşdeğer şekilde belirlenmekteydi. Avrupa Birliği ve diğer gelişmiş ülkelerde UFRS'nin uygulama kapsamının yalnızca borsada işlem gören işletmelerle sınırlı olduğu ve borsada işlem görmeyen işletmeler için uygulanması daha basit ve daha az maliyetli olan finansal raporlama çerçeveleri oluşturulduğu görülmektedir. Bu bağlamda KGK'nın 2014 tarihli bu kararı ile TMS'lerin uygulama kapsamı bağımsız denetim kapsamından ayrıştırılmış ve diğer ülke uygulamalarına benzer şekilde genel olarak kamu yararını ilgilendiren kuruluşlarla sınırlı tutulmuştur (KGK, 2017a).

TMS/TFRS'yi uygulamayan işletmelerin KGK tarafindan bir belirleme yapılana kadar yürürlükteki mevzuatı uygulamaları kararlaştırılmıştır. Bu kapsamdaki işletmelerin uygulayacakları geçerli finansal raporlama çerçevesi, Muhasebe Sistemi Uygulama Genel Tebliğleri (MSUGT) olarak belirlenmiştir. Bağımsız denetime tabi olup TMS/TFRS uygulamayan işletmelerin münferit ve konsolide finansal tablolarının karşılaştırılabilir, gerçeğe ve ihtiyaca uygun bilgi sağlamasını temin etmek üzere Büyük ve Orta Boy İşletmeler İçin Finansal Raporlama Standardı (BOBİ FRS) 29 Temmuz 2017 tarihinde Resmi Gazetede yayınlanmıştır (TÜRMOB, 2017).

KGK verilerine göre 2016 yılında bağımsız denetim sözleşmesi uygulayan 6.250 işletmeden KAYİK sınıfına giren 1.550 işletme TFRS uygulamakta geriye kalan 4.700 işletme ise $1 / 1 / 2018$ ' den itibaren BOBİ FRS'yi uygulayacaktır (KGK, 2017b). Türkiye'de ticaret ve sanayi odalarına kayıtlı işletme sayıları İç Ticaret Genel Müdürlügü verilerine göre 2014 yılı Haziran ayı itibariyle 1.351.212'dir (Gümrük ve Ticaret Bakanlığı, 2017). Bu verilere göre toplam işletme sayısı içinde KAYIKK'lerin oranı binde 1,14 iken BOBI'lerin oranı binde 3,47'dir. Dolayısıyla Türkiye'de standartlara göre tablo hazırlayan işletme sayısının bu kadar 
düşük olması üniversitelerin muhasebe eğitiminde bu konuya gerektiği kadar yer vermemelerine neden olmaktadir.

\section{MUHASEBE STANDARTLARININ MUHASEBE EĞITIMINE ETKİSi}

Ülkemizde muhasebe alanında yapılan çeşitli düzenlemelerin muhasebe eğitimi üzerinde önemli etkilere sahip olduğu görülmektedir (Hatunoğlu, Kıllı, 2014:230). Ülkemizde muhasebe eğitimini etkileyen düzenlemelere 1994 yılından itibaren uygulanmaya başlanan Tekdüzen Muhasebe Sistemi (TDMS) örnek olarak verilebilir. Ülkemizde muhasebe eğitimini etkileyen en son düzenleme ise TMS/TFRS uygulamalarıdır. TMS/TFRS uygulaması muhasebe eğitiminde yeni bir dönem başlatmıştır. Ülkemizde üniversitelerde muhasebe eğitimi ön lisans, lisans ve lisansüstü düzeylerde verilmektedir. Üniversitelerin muhasebe eğitimi verilen bölümlerinden mezun olan öğrenciler muhasebe meslek elemanı olarak mesleğin çeşitli aşamalarında görev almaktadır. Bu bağlamda üniversitede verilen muhasebe eğitiminin güncel muhasebe bilgilerini içermesi, muhasebe mesleğinde yaşanan gelişmelere paralel olarak muhasebe ders müfredatlarının hızlı bir şekilde güncellenmesi gerekmektedir. Muhasebe alanında meydana gelen değişiklikleri yakından takip etmek ve öğrencilere aktarmak konusunda muhasebe öğretim elemanları önemli görevler üstlenmektedirler.

Muhasebe yazınında muhasebe standartlarının uygulanma sürecinde yaşanan sorunlar üzerine yapılan çalışmalara bakıldığında en önemli sorunun eğitim eksikliği olduğu görülmektedir (Çankaya, Hatipoğlu, 2011: 83; Aktürk, 2014: 81). TMS/TFRS uygulama sürecinde en önemli sorunlardan birinin eğitim eksikliği olması nedeniyle muhasebe meslek mensubu adaylarını yetiştiren üniversitelerde muhasebe standartlarına ilişkin derslerin okutulması, muhasebe ders içeriklerinin TMS/TFRS'leri kapsayacak şekilde güncelleştirilmesi ve muhasebe meslek odalarının üniversiteler ile işbirliği içinde muhasebe standartları eğitim programları düzenleyerek, muhasebe meslek mensuplarının TMS/TFRS setini kapsayacak şekilde muhasebe standartları eğitimi almalarının sağlanması gerekmektedir (Gökçen vd., 2015: 127).

\section{LITERATÜR İNCELEMESI}

Muhasebe ve finansal raporlama standartları eğitimine ilişkin literatürde yer alan uluslararası ve ulusal çalışmalardan bazılarına aşağıda yer verilmiştir.

Carvalho ve Salotti (2013), Brezilya'da UFRS'ye geçilmesinden önceki ve sonraki dönemlerde muhasebe eğitimini karşılaştırdıkları çalışmada, 2008'den önce muhasebe eğitiminde kural bazlı bir yaklaşım izlendiği ve özellikle vergi kurallarının muhasebe uygulamalarının temelini oluşturduğu, UFRS'nin kabulü ile ilke bazlı muhasebe eğitimine geçilmesinin Brezilya muhasebe eğitiminde gerçek bir devrimi temsil ettiği görüşünü paylaşmaktadırlar.

Jackling ve diğerleri (2013) tarafından yapılan çalışmada muhasebe eğiticilerinin UFRS'ye geçişten önce hissettikleri endişelere rağmen Avusturalya Genel Kabul Görmüş Muhasebe İlkeleri ile UFRS arasındaki benzerliğin geçiş sürecinde muhasebe eğitimi üzerinde sınırlı bir etki yarattığı ve mevcut eğitim materyallerinin UFRS ile uyumlu olacak şekilde güncellenmesi gerektiği belirtilmektedir. 
Gökçen ve diğerleri (2015) tarafından yapılan çalışmada, Türkiye'deki devlet üniversitelerinin İșletme bölümlerinde muhasebe ve finansal raporlama standartlarına ilişkin dersler ve içeriklerinin TMS/TFRS'ye uyumu araştırılmıştır. Çalışmada, devlet üniversitelerinin İşletme bölümlerinde muhasebe standartları eğitimine gereken önemin verilmediği ve dersin verildiği bölümlerde de ders içeriklerinin TMS/TFRS setini kapsamadığı belirlenmiştir.

Daştan ve Bellikli (2016), TMS/TFRS'nin muhasebe eğitimindeki yerini, üniversitelerde lisans ve lisansüstü düzeylerde verilen muhasebe eğitimi ile muhasebe meslek sınavları çerçevesinde araştırarak TMS/TFRS eğitiminde ideali arayış çabalarına katkıda bulunmayı amaçlamışlardır. Araştırma kapsamında, lisans ve lisansüstü programlarda verilen muhasebe derslerinin ad ve içerik analiziyle meslek sınavlarında sorulan sorular incelenmiştir. Çalışmada, muhasebe eğitiminde TMS/TFRS açısından ideali yakalayabilmek için Tekdüzen Hesap Planı'nın (THP) temel alınması ve THP'nin TMS/TFRS içeriği ve felsefesine uygun olarak güncellenmesi ve geliştirilmesi gerektiği önerilmiştir.

Durer ve diğerleri (2016) yaptıkları çalışmada, UFRS'nin muhasebe eğitimine dahil edilmesi konusunda Türkiye'deki üniversitelerde muhasebe eğitimi veren akademisyenlerin görüşlerini öğrenmeyi amaçlamışlardır. Çalışmada, akademisyenlerin muhasebe eğitiminde MSUGT, vergi yasaları ve UFRS'ye eşit oranda yer verilmesinin yönünde görüş bildirdikleri tespit edilmiştir.

Koçyiğit ve Tanç (2016), Türkiye'deki üniversitelerin muhasebe eğitimi verilen lisansüstü muhasebe ve işletme programlarında muhasebe standartlarına ilişkin derslerin verilme düzeyi ve ders içeriklerinin TMS/TFRS setine uyumunu ortaya koymak amacıyla yaptıkları çalışmada, standartlara ilişkin derslerin ve içeriklerinin TMS/TFRS tam setini karşılamadığı sonucuna ulaşmışlardır.

Karcıoglu ve Dizman (2016), TMS/TFRS kapsamında verilen muhasebe eğitiminin kalite standartları açısından yeterliliğini araştırmak amacıyla yaptıkları çalışmada, Lise, Yüksekokul, Fakülte, Yüksek Lisans ve Doktora düzeylerinde muhasebe dersi almış öğrencilerin, aldıkları eğitimi kalite standartları açısından yeterli görüp görmediklerini tespit etmeyi amaçlamışlardır. Çalışmada, öğrencilerin en yüksek yeterlilikleri lise düzeyinde, en düşük yeterlilikleri ise doktora düzeyinde gördükleri sonucuna ulaşılmıştır.

Türkiye'deki üniversitelerde TMS/TFRS eğitiminin incelendiği bu çalışmanın literatürdeki diğer çalışmalardan farkı;

- Hem devlet hem de vakıf üniversitelerini inceleme kapsamına alması,

- TMS/TFRS eğitiminin verilme durumunu lisans, yüksek lisans ve doktora düzeyinde ele alması,

- İnceleme kapsamına sadece işletme bölümlerini değil muhasebe eğitimi verilen diğer lisans ve lisansüstü bölüm ve programları da dahil etmesi ve daha güncel verilerin kullanılmasıdır. 


\section{ARAŞTIRMA METHODOLOJISİ}

\section{A. ARAŞTIRMANIN AMACI}

Bu çalışma, Türkiye'deki üniversitelerde lisans ve lisansüstü düzeyde muhasebe eğitimi verilen bölüm ve programlarda muhasebe/finansal raporlama standartları eğitiminin verilip verilmediği, veriliyorsa derslerin hangi isimle verildiği, zorunlu mu seçmeli mi olduğu, haftalık ders saatlerinin belirlenmesi ve ders içeriklerinin incelenmesi amacıyla yapılmıştır. Bu amaçla, 2016 yılı Haziran ayı itibariyle, Yükseköğretim Kurulu'na bağlı devlet ve vakıf üniversiteleri bünyesinde muhasebe eğitimi verilen fakülte ve yüksekokullardaki lisans programları (İşletme, Muhasebe, Muhasebe ve Denetim, Muhasebe ve Finansal Yönetim, Muhasebe Bilgi Sistemleri) ve lisansüstü programları (İşletme, Muhasebe, MuhasebeFinansman, Muhasebe- Denetim) incelenmiştir.

\section{B. ARAŞTIRMANIN YÖNTEMI}

$\mathrm{Bu}$ araştırmada yöntem olarak tanımlayıcı araştırma modeli kullanılmıştır. Tanımlayıcı araștırma modeli, bir tür verileri gruplandırma ve sınıflandırma, olayları sistemli olarak tanımlama, nesneleri listeleme çalışmaları olarak tanımlanmaktadır (Usta, 2012: 147). Çalışmada, Türkiye'deki devlet ve vakıf üniversiteleri bünyesinde bulunan ilgili fakülte, yüksekokul ve enstitülerin muhasebe eğitimi verilen bölümlerinin internet sayfaları taranarak ders planları ve ders içerikleri incelenmiş ve muhasebe/finansal raporlama standartlarına ilişkin derslerin verilme düzeyi tespit edilmiştir.

\section{ARASSTIRMANIN KAPSAMI}

Araştırmanın kapsamını Türkiye'deki üniversitelerde lisans düzeyinde muhasebe eğitimi verilen fakülte ve yüksekokullar ile lisansüstü düzeyde muhasebe eğitimi verilen sosyal bilimler enstitülerinin ilgili bölümleri oluşturmaktadır. Türkiye'de Haziran 2016 tarihi itibariyle Yükseköğretim Kurulu'na bağlı olarak faaliyet gösteren 109 devlet ve 76 vakıf üniversitesi olmak üzere toplam 185 üniversite bulunmaktadır (Yüksek Öğretim Kurumu, 2016). Üniversitelerde muhasebe eğitimi, İktisadi ve İdari Bilimler Fakülteleri başta olmak üzere, İşletme Fakülteleri, İktisat Fakülteleri, Siyasal Bilgiler Fakülteleri, Sosyal ve Beşeri Bilimler Fakülteleri, Yönetim Bilimleri Fakülteleri, İşletme ve Yönetim Bilimleri Fakülteleri, İktisadi, İdari ve Sosyal Bilimler Fakülteleri, Ticari Bilimler Fakülteleri, Uygulamalı Bilimler Fakülteleri, Uygulamalı Bilimler Yüksekokulları, Uygulamalı Teknoloji ve İşletmecilik Yüksekokulları, Açık Öğretim Fakülteleri ile Açık ve Uzaktan Öğretim Fakültelerinde verilmektedir.

\section{BULGULAR}

\section{A. LISANS DÜZEYINDE TMS/TFRS EĞíTiMINE İLIŞKİN BULGULAR}

Lisans düzeyinde muhasebe eğitimi verilen fakülte ve yüksekokulların devlet ve vakıf üniversitelerindeki dağılımı Tablo 1'de verilmiştir. 
Tablo 1: Lisans Düzeyinde Muhasebe Eğitimi Verilen Fakülte ve Yüksekokullar

\begin{tabular}{lccc}
\hline Fakülteler & Devlet & Vakıf & Toplam \\
\hline İktisadi ve İdari Bilimler Fakültesi (İ̈BF) & 92 & 32 & 124 \\
İşletme Fakültesi & 21 & 8 & 29 \\
İktisat Fakültesi & 4 & 0 & 4 \\
\hline Siyasal Bilgiler Fakültesi & 8 & 1 & 9 \\
Sosyal ve Beşeri Bilimler Fakültesi & 4 & 2 & 6 \\
\hline Yönetim Bilimleri Fakültesi & 1 & 1 & 2 \\
İşletme ve Yönetim Bilimleri Fakültesi & 0 & 7 & 7 \\
İktisadi İdari ve Sosyal Bilimler Fakültesi & 0 & 12 & 12 \\
Tícari Bilimler Fakültesi & 0 & 3 & 3 \\
Uygulamalı Bilimler Fakültesi & 4 & 2 & 6 \\
Uygulamalı Bilimler Yüksekokulu (UBYO) & 7 & 4 & 11 \\
\hline Uygulamalı Teknoloji ve İşletmecilik YO & 3 & 0 & 3 \\
Açık Öğretim Fakülteleri & 2 & 0 & 2 \\
\hline Açık ve Uzaktan Eğitim Fakültesi & 1 & 0 & 1 \\
\hline Toplam & $\mathbf{1 4 7}$ & $\mathbf{7 2}$ & $\mathbf{2 1 9}$ \\
\hline
\end{tabular}

Tablo 1'de görüldüğü gibi devlet üniversitelerinde 147, vakıf üniversitelerinde 72 olmak üzere toplam 219 fakülte ve yüksekokulda muhasebe eğitimi verilmektedir. Muhasebe eğitimi verilen fakülteler arasında 92'si devlet ve 32'si vakıf üniversitelerinde olmak üzere toplam 124 adet fakülte ile İİBF'ler ilk sırada yer almaktadırlar. Türkiye'deki üniversitelerden 26 devlet ve 6 vakıf üniversitesinde muhasebe eğitimi birden fazla fakülte ve yüksekokulda verilmektedir.

Ülkemizde 33 devlet üniversitesinde 41 UBYO, 11 vakıf üniversitesinde 12 UBYO olmak üzere toplam 53 UBYO bulunmaktadır. Uygulamalı Teknoloji ve İşletmecilik Yüksekokulu sayıları ise 4 devlet üniversitesinde 6 yüksekokul, 1 vak1f üniversitesinde ise 1 yüksekokul olmak üzere toplam 7 tanedir (Yüksek Öğretim Kurumu, 2016). Ancak Tablo 1'de bu yüksekokullardan bünyesinde muhasebe eğitimi verilen bölüme sahip olanlara yer verilmiştir.

Muhasebe eğitimi verilen bölüm sayılarının tespit edilmesinde Ölçme Seçme ve Yerleştirme Merkezinin (ÖSYM) 2015 y1lı Ölçme Seçme ve Yerleştirme S1navı (ÖSYS) merkezi yerleştirme ile öğrenci alan lisans programlarına yerleştirme sonuçlarının yer aldığı tablo esas alınmıştır.

2015 y1lı itibariyle öğrenci alan işletme bölümlerinin, bulundukları fakülte ve yüksekokullara dağılımı ve eğitim dilleri Tablo 2'de gösterilmiştir. 
Tablo 2: İşletme Lisans Bölümlerinin Devlet ve Vakıf Üniversitelerine Dağılımı

\begin{tabular}{|c|c|c|c|c|c|c|c|}
\hline \multirow[b]{2}{*}{ Fakülte/YO } & \multicolumn{4}{|c|}{$\begin{array}{c}\text { Devlet } \\
\text { Üniversiteleri }\end{array}$} & \multicolumn{3}{|c|}{ Vakıf Üniversiteleri } \\
\hline & 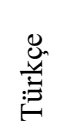 & 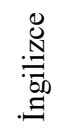 & 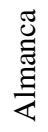 & $\frac{\tilde{E}}{\stackrel{\Xi}{0}}$ & 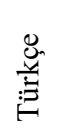 & 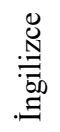 & $\frac{\Xi}{\frac{\pi}{2}}$ \\
\hline İ̈̈BF & 84 & 10 & 1 & 95 & 21 & 20 & 41 \\
\hline İşletme Fakültesi & 14 & 6 & 1 & 21 & 4 & 7 & 11 \\
\hline İktisat Fakültesi & 1 & 0 & 0 & 1 & 0 & 0 & $\mathbf{0}$ \\
\hline Siyasal Bilgiler Fakültesi & 4 & 0 & 0 & 4 & 0 & 0 & $\mathbf{0}$ \\
\hline Sosyal ve Beşeri Bilimler Fak. & 2 & 0 & 0 & 2 & 0 & 0 & $\mathbf{0}$ \\
\hline Yönetim Bilimleri Fakültesi & 0 & 1 & 0 & 1 & 0 & 0 & $\mathbf{0}$ \\
\hline İşletme ve Yönetim Bilimleri Fak. & 0 & 0 & 0 & $\mathbf{0}$ & 3 & 5 & 8 \\
\hline İktisadi, İdari ve Sosyal Bilimler Fak. & 0 & 0 & 0 & $\mathbf{0}$ & 4 & 6 & 10 \\
\hline Ticari Bilimler Fakültesi & 0 & 0 & 0 & $\mathbf{0}$ & 1 & 1 & 2 \\
\hline Açık Öğretim Fakülteleri & 1 & 0 & 0 & 1 & 0 & 0 & $\mathbf{0}$ \\
\hline Açık ve Uzaktan Eğitim Fakültesi & 1 & 0 & 0 & 1 & 0 & 0 & $\mathbf{0}$ \\
\hline Toplam & 107 & 17 & 2 & 126 & 33 & 39 & 72 \\
\hline
\end{tabular}

Tablo 2'de görüldüğü gibi işletme bölümü sayısı devlet üniversitelerinde 126, vakıf üniversitelerinde ise 72' dir. Devlet üniversiteleri bünyesindeki işletme bölümlerinin 107'sinde Türkçe, 17'sinde İngilizce, 2'sinde ise Almanca eğitim verilmektedir. Vakıf üniversiteleri bünyesindeki işletme bölümlerinin 33'ünde Türkçe eğitim verilirken 39'unda ise İngilizce eğitim verilmektedir.

2016 y1lı itibariyle öğrenci alan Muhasebe (Muhasebe ve Denetim, Muhasebe ve Finansal Yönetim, Muhasebe Bilgi Sistemleri dahil) lisans bölümlerinin, bulundukları fakülte ve yükssekokullara dağılımı ve eğitim dilleri Tablo 3'de gösterilmiştir.

Tablo 3: Muhasebe Lisans Bölümlerinin Devlet ve Vakıf Üniversitelerine Dağılımı

\begin{tabular}{|c|c|c|c|c|c|}
\hline \multirow[b]{2}{*}{ Fakülte ve Yüksekokullar } & \multicolumn{2}{|c|}{ Devlet Üniversiteleri } & \multicolumn{3}{|c|}{$\begin{array}{c}\text { Vakıf } \\
\text { Üniversiteleri }\end{array}$} \\
\hline & 苍 & $\frac{\Xi}{\tilde{a}}$ & 芯 & 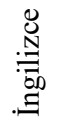 & $\frac{\tilde{\Xi}}{\frac{\Xi}{2}}$ \\
\hline İंBF & 0 & $\mathbf{0}$ & 1 & 0 & 1 \\
\hline İşletme Fakültesi & 0 & $\mathbf{0}$ & 0 & 1 & 1 \\
\hline İktisadi, İdari ve Sosyal Bilimler Fak. & 0 & $\mathbf{0}$ & 1 & 0 & 1 \\
\hline Ticari Bilimler Fakültesi & 0 & $\mathbf{0}$ & 2 & 0 & 2 \\
\hline Uygulamalı Bilimler Fakültesi & 0 & $\mathbf{0}$ & 1 & 0 & 1 \\
\hline Uygulamalı Bilimler YO & 7 & 7 & 4 & 0 & 4 \\
\hline Uygulamalı Teknoloji ve İşletmecilik YO & 1 & 1 & 0 & 0 & $\mathbf{0}$ \\
\hline Toplam & 8 & 8 & 9 & 1 & 10 \\
\hline
\end{tabular}


Tablo 3 incelendiğinde devlet üniversitelerinde bulunan 8 muhasebe lisans programının 7'sinin UBYO'da, 1'inin de Uygulamalı Teknoloji ve İşletmecilik Yüksekokulunda bulunduğu görülmektedir. Vakıf üniversitelerinde bulunan 10 muhasebe programının 6'sının fakültelerde, 4'ünün UBYO'larda bulunduğu görülmektedir. Devlet üniversitelerindeki muhasebe lisans programlarının tamamında Türkçe eğitim yapılırken, vakıf üniversitelerinde bulunan muhasebe lisans programlarının 1'inde İngilizce eğitim yapılmakta diğerlerinde Türkçe eğitim yapilmaktadır.

Muhasebe eğitimi verilen İşletme ve Muhasebe bölümlerinin ders planları incelenmiş; araştırma muhasebe standartları, finansal raporlama standartları, uluslararası muhasebe standartları, Türkiye muhasebe standartları, uluslararası finansal raporlama standartları gibi kavramları içeren dersler ile sınırlandırılmıştır. Çalışmada öncelikle lisans düzeyinde muhasebe eğitimi verilen fakülte ve yüksekokullardan müfredatlarında standartlarla ilgili ders bulunanlar incelenmiş ve Tablo 4'te verilmiştir.

Tablo 4: Müfredatlarında TMS/TFRS Dersi Bulunan Fakülte ve Yüksekokullar Devlet
Üniversiteleri

Vakıf Üniversiteleri

Fakülte ve Yüksekokullar

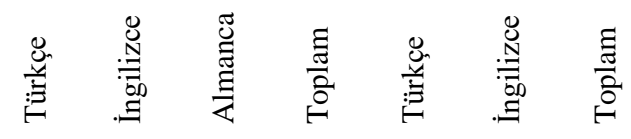

\begin{tabular}{lccccccc}
\hline İ.İ.B.F. & 32 & 2 & 1 & $\mathbf{3 5}$ & 8 & 4 & $\mathbf{1 2}$ \\
İşletme Fakültesi & 4 & 0 & 1 & $\mathbf{5}$ & 2 & 3 & $\mathbf{5}$ \\
İktisat Fakültesi & 1 & 0 & 0 & $\mathbf{1}$ & 0 & 0 & $\mathbf{0}$ \\
Sosyal Beşeri Bilimler Fakültesi & 1 & 0 & 0 & $\mathbf{1}$ & 0 & 0 & $\mathbf{0}$ \\
İşletme ve Yönetim Bilimleri Fak. & 0 & 0 & 0 & $\mathbf{0}$ & 1 & 0 & $\mathbf{1}$ \\
İktisadi, İdari ve Sosyal Bilimler & 0 & 0 & 0 & $\mathbf{0}$ & 5 & 4 & $\mathbf{9}$ \\
Uygulamalı Bilimler Yüksekokulu & 5 & 0 & 0 & $\mathbf{5}$ & 2 & 0 & $\mathbf{2}$ \\
Uygulamalı Teknoloji ve İşletmecilik YO & 1 & 0 & 0 & $\mathbf{1}$ & 0 & 0 & $\mathbf{0}$ \\
\hline Toplam & $\mathbf{4 4}$ & $\mathbf{2}$ & $\mathbf{2}$ & $\mathbf{4 8}$ & $\mathbf{1 8}$ & $\mathbf{1 1}$ & $\mathbf{2 9}$ \\
\hline
\end{tabular}

Tablo 4 incelendiğinde devlet üniversitelerinde 48, vakıf üniversitelerinde ise 29 bölümde TMS/TFRS dersi verildiği görülmektedir. Bu sayıları sırasıyla devlet ve vakıf üniversitelerinde muhasebe eğitimi verilen bölüm sayılarına oranlayacak olursak; devlet üniversitelerinde 126 işletme ve 8 muhasebe bölümü olmak üzere toplam 134 bölümün \%36'sında, vakıf üniversitelerinde ise 72 işletme ve 10 muhasebe bölümü olmak üzere 82 bölümün $\% 35$ 'inde muhasebe standartları dersi verilmektedir.

Üniversitelerde muhasebe eğitimi verilen en çok bölümü sahip olan İ̈BF'lerdeki bölüm sayılarını muhasebe eğitimi verilen bölüm sayılarına oranlayacak olursak; devlet üniversitelerinde İIBF bünyesinde bulunan 95 bölümün \%37'sinin müfredatlarında, vakıf üniversitelerindeki İ̈BF bünyesinde bulunan 42 
bölümün ise \%29'unun müfredatlarında muhasebe standartlarına ilişkin ders olduğu görülmüsstür.

Diğer fakültelerdeki oranlara bakıldığında devlet üniversitelerinde İşletme Fakültelerinin \%24'ünde, muhasebe eğitimi verilen bölüme sahip UBYO'ların \%71'inde TMS/TFRS dersi bulunmaktadır. Vakıf üniversitelerinde, İktisadi, İdari ve Sosyal Bilimler Fakültelerinin \%82'sinde, İşletme Fakültelerinin \%42'sinde, UBYO'ların \%50'sinde TMS/TFRS dersi bulunmaktadır.

\section{B. YÜKSEK LISSANS DÜZEYINDE TMS/TFRS EĞITTIMİNE İLIŞKIN BULGULAR}

Üniversitelerimizde yüksek lisans düzeyinde muhasebe eğitimi verilen ana bilim/bilim dallarının devlet ve vakıf üniversitelerindeki dağılımı Tablo 5'te verilmiştir.

Tablo 5: Yüksek Lisans Düzeyinde Muhasebe Eğitimi Verilen Programlar

\begin{tabular}{|c|c|c|c|c|c|c|}
\hline \multirow[b]{2}{*}{ Ana Bilim/Bilim Dalı } & \multicolumn{3}{|c|}{ Devlet Üniversiteleri } & \multicolumn{3}{|c|}{ Vakıf Üniversiteleri } \\
\hline & 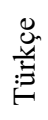 & 芯 & $\frac{\Xi}{\frac{\Xi}{2}}$ & 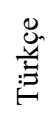 & 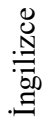 & $\frac{\Xi}{\frac{\Xi}{0}}$ \\
\hline İşletme & 70 & 5 & 75 & 57 & 11 & 68 \\
\hline Muhasebe-Finansman & 7 & 2 & 9 & 3 & 2 & 5 \\
\hline Muhasebe & 4 & 0 & 4 & 4 & 0 & 4 \\
\hline Muhasebe- Denetim & 3 & 0 & 3 & 9 & 0 & 9 \\
\hline Toplam & 84 & 7 & 91 & 73 & 13 & 86 \\
\hline
\end{tabular}

Tablo 5 incelendiğinde devlet üniversitelerinde 70'i Türkçe ve 5'i İngilizce eğitim yapan 75 İşletme yüksek lisans programı, 7'si Türkçe ve 2'si İngilizce eğitim yapan 9 Muhasebe-Finansman yüksek lisans programı, Türkçe eğitim yapan 4 Muhasebe ve 3 Muhasebe-Denetim yüksek lisans programı olduğu görülmektedir. Vakıf üniversitelerinde ise 57'si Türkçe ve 11 İngilizce eğitim yapan 68 işletme yüksek lisans programı, 3'ü Türkçe ve 2'si İngilizce muhasebe-finansman yüksek lisans programı, Türkçe eğitim yapan 4 muhasebe ve 9 muhasebe-denetim yüksek lisans programı bulunmaktadır.

Tablo 6' da devlet ve vakıf üniversitelerindeki yüksek lisans düzeyinde muhasebe eğitimi verilen ana bilim/bilim dallarının müfredatları incelenmiş ve müfredatlarında muhasebe standartları dersi bulunan programların dağılımı verilmiştir. Devlet üniversitelerde 46, vakıf üniversitelerinde ise 28 Yüksek Lisans programında TMS/TFRS dersi verilmektedir.

Tablo 6 incelendiğinde TMS/TFRS derslerinin devlet üniversitelerinde 27'si Türkçe ve 1'i İngilizce eğitim yapan 28 işletme yüksek lisans programında, 10'u Türkçe ve 3'ü İngilizce eğitim yapan 13 Muhasebe-Finansman yüksek lisans programında, Türkçe eğitim yapan 3 Muhasebe ve biri Türkçe diğeri İngilizce eğitim yapan 2 Muhasebe ve Denetim yüksek lisans programında verildiği tespit edilmiştir. Vakıf üniversitelerinde ise 11 'i Türkçe ve 4'ü İngilizce eğitim yapan 
15 İşletme yüksek lisans programında, 2'si Türkçe ve 1'i İngilizce eğitim yapan 3 Muhasebe-Finansman yüksek lisans programında, Türkçe eğitim yapan $10 \mathrm{Mu}-$ hasebe ve Denetim yüksek lisans programında TMS/TFRS dersi müfredatlarda tespit edilmiştir.

Tablo 6: Devlet ve Vakıf Üniversitelerinde Yüksek Lisans Eğitiminde TMS/TFRS Dersleri Verilen Program Sayıları

\begin{tabular}{|c|c|c|c|c|c|c|}
\hline \multirow[b]{2}{*}{ Ana Bilim/Bilim Dalı } & \multicolumn{3}{|c|}{$\begin{array}{c}\text { Devlet } \\
\text { Üniversiteleri }\end{array}$} & \multicolumn{3}{|c|}{ Vakıf Üniversiteleri } \\
\hline & \begin{tabular}{l}
$\stackrel{8}{\mathscr{y}}$ \\
\hdashline$\vdots \Xi$ \\
$\vdots$
\end{tabular} & 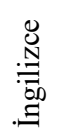 & 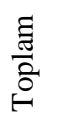 & $\begin{array}{l}\mathscr{\mathscr { U }} \\
\stackrel{y}{\Xi}\end{array}$ & 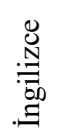 & $\frac{\Xi}{\Xi}$ \\
\hline İşletme & 27 & 1 & 28 & 11 & 4 & 15 \\
\hline Muhasebe- Finansman & 10 & 3 & 13 & 2 & 1 & 3 \\
\hline Muhasebe & 3 & 0 & 3 & 0 & 0 & 0 \\
\hline Muhasebe - Denetim & 1 & 1 & 2 & 10 & 0 & 10 \\
\hline Toplam & 41 & 5 & 46 & 23 & 5 & 28 \\
\hline
\end{tabular}

Devlet ve vakıf üniversitelerinde muhasebe eğitimi verilen Yüksek Lisans programları arasında TMS/TFRS eğitimi verilen programların oranlarına bakılacak olursa; devlet üniversitelerindeki 91 Yüksek Lisans programının \%51'inde, vakıf üniversitelerindeki 86 Yüksek Lisans programının \%33'ünde TMS/TFRS dersinin müfredatlarda yer aldığı tespit edilmiştir. Devlet üniversitelerindeki yüksek lisans programlarında vakıf üniversitelerine oranla daha fazla TMS/TFRS dersi verildiği görülmektedir.

\section{DOKTORA DÜZEYINDE TMS/TFRS EĞITIMINE İLIŞKİN BULGULAR}

Tablo 7'de üniversitelerimizde doktora düzeyinde muhasebe eğitimi verilen ana bilim/bilim dallarının devlet ve vakıf üniversitelerindeki dağılımı verilmiştir.

Tablo 7: Doktora Düzeyinde Muhasebe Eğitimi Verilen Programlar

\begin{tabular}{|c|c|c|c|c|c|c|}
\hline \multirow[b]{2}{*}{ Ana Bilim/Bilim Dalı } & \multicolumn{3}{|c|}{ Devlet Üniversiteleri } & \multicolumn{3}{|c|}{ Vakıf Üniversiteleri } \\
\hline & 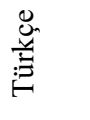 & 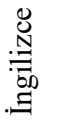 & $\frac{\Xi}{\frac{\Xi}{2}}$ & 总 & 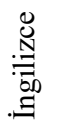 & $\frac{\Xi}{\frac{\Xi}{0}}$ \\
\hline İşletme & 56 & 2 & 58 & 27 & 12 & 39 \\
\hline Muhasebe- Finansman & 5 & 0 & 5 & 2 & 0 & 2 \\
\hline Muhasebe & 1 & 0 & 1 & 0 & 0 & 0 \\
\hline Muhasebe- Denetim & 0 & 0 & 0 & 4 & 1 & 5 \\
\hline Toplam & 62 & 2 & 64 & 33 & 13 & 46 \\
\hline
\end{tabular}

Tablo 7 incelendiğinde devlet üniversitelerinde 56 Türkçe ve 2 İngilizce eğitim yapan 58 İşletme doktora programı, Türkçe eğitim yapan 5 Muhasebe-Finans- 
man ve 1 Muhasebe doktora programı olduğu görülmektedir. Vakıf üniversitelerinde ise 27 Türkçe ve 12 İngilizce eğitim yapan 39 işletme doktora program1, Türkçe eğitim yapan 2 muhasebe-finansman doktora programı, 4 Türkçe ve 1 İngilizce Muhasebe Denetim doktora programı olduğu tespit edilmiştir.

Tablo 8'de devlet ve vakıf üniversitelerindeki doktora düzeyinde muhasebe eğitimi verilen ana bilim/bilim dallarının müfredatları incelenmiş ve müfredatlarında muhasebe standartları dersi bulunun programların dağılımı verilmiştir.

Tablo 8: Devlet ve Vakıf Üniversitelerinde Doktora Eğitiminde TMS/TFRS Derslerinin Verilme Durumu

\begin{tabular}{|c|c|c|c|c|c|c|}
\hline \multirow[b]{2}{*}{ Ana Bilim/Bilim Dalı } & \multicolumn{3}{|c|}{ Devlet Üniversiteleri } & \multicolumn{3}{|c|}{ Vakıf Üniversiteleri } \\
\hline & 总 & 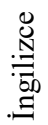 & $\frac{\Xi}{\frac{\Xi}{0}}$ & 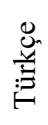 & 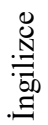 & $\frac{\Xi}{\frac{\Xi}{2}}$ \\
\hline İşletme & 23 & 0 & 23 & 8 & 2 & 10 \\
\hline Muhasebe- Finansman & 3 & 0 & 0 & 2 & 0 & 2 \\
\hline Muhasebe & 0 & 0 & 0 & 0 & 0 & 0 \\
\hline Muhasebe-Denetim & 0 & 0 & 0 & 4 & 0 & 4 \\
\hline Toplam & 26 & 0 & 26 & 14 & 2 & 16 \\
\hline
\end{tabular}

Tablo 8 incelendiğinde devlet üniversitelerinde 23'ü işletme, 3 'ü MuhasebeFinansman olmak üzere toplam 26 doktora programinda TMS/TFRS ile ilgili derslerin müfredatta olduğu görülmektedir. Vakıf üniversitelerinde ise 8'i Türkçe ve 2'si İngilizce olmak üzere 10 İşletme, 2 Muhasebe-Finansman ve 4 MuhasebeDenetim olmak üzere 16 doktora programında TMS/TFRS ile ilgili derslerin müfredatlarda olduğu tespit edilmiştir.

Devlet ve vakıf üniversitelerinde muhasebe eğitimi verilen doktora programları arasında TMS/TFRS eğitimi verilen programların oranlarına bakılacak olursa; devlet üniversitelerinde 64 Doktora programının \%41'inde, vakıf üniversitelerinde ise 46 Doktora programının \%35'inde TMS/TFRS dersinin müfredatlarda yer aldığı tespit edilmiştir.

\section{TMS/TFRS EĞİTIMININ VERILDİĞİ DERS İSIMLERİ}

Üniversitelerimizde verilmekte olan TMS/TFRS derslerinin isimleri Tablo 9'da verilmiştir. 
Tablo 9: Devlet ve Vakıf Üniversitelerinde Lisans Düzeyinde Verilen TMS/TFRS Derslerinin İsimleri

Devlet Üniversiteleri Vakıf Üniversiteleri

Ders İsimleri

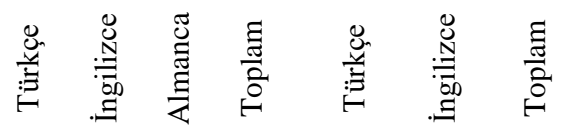

\begin{tabular}{|c|c|c|c|c|c|c|c|}
\hline Muhasebe Standartları & 17 & 1 & 0 & 18 & 3 & 1 & 4 \\
\hline Muhasebe Standartları I & 4 & 0 & 0 & 4 & 1 & 0 & 1 \\
\hline Muhasebe Standartları II & 4 & 0 & 0 & 4 & 1 & 0 & 1 \\
\hline Muhasebe Standartları ve Uygulamaları & 1 & 0 & 0 & 1 & 0 & 0 & 0 \\
\hline Türkiye Muhasebe Standartları & 2 & 0 & 0 & 2 & 0 & 0 & 0 \\
\hline Türkiye Muhasebe Standartları-I & 2 & 0 & 0 & 2 & 0 & 0 & 0 \\
\hline Türkiye Muhasebe Standartları-II & 2 & 0 & 0 & 2 & 0 & 0 & 0 \\
\hline Türkiye Muhasebe Standartları Uygulamaları & 1 & 0 & 0 & 1 & 0 & 0 & 0 \\
\hline Finansal Raporlama Standartları & 6 & 0 & 0 & 6 & 1 & 1 & 2 \\
\hline Finansal Raporlama ve Muhasebe Standartları & 1 & 0 & 0 & 1 & 0 & 0 & 0 \\
\hline KOBİ'lerde Finansal Muhasebe Standartları & 1 & 0 & 0 & 1 & 0 & 0 & 0 \\
\hline Türkiye Finansal Raporlama Standartları & 1 & 0 & 0 & 0 & 0 & 0 & 0 \\
\hline Türkiye Finansal Raporlama Standartları I & 0 & 0 & 0 & 0 & 1 & 0 & 1 \\
\hline Türkiye Finansal Raporlama Standartları II & 0 & 0 & 0 & 0 & 1 & 0 & 1 \\
\hline Türkiye Muhasebe/Finansal Raporlama Standart. & 2 & 0 & 0 & 2 & 0 & 0 & 0 \\
\hline Uluslararası Muhasebe Standartları & 0 & 1 & 1 & 2 & 4 & 2 & 6 \\
\hline Uluslararası Muhasebe Standartları I & 1 & 0 & 1 & 2 & 1 & 1 & 2 \\
\hline Uluslararası Muhasebe Standartları II & 1 & 0 & 1 & 2 & 1 & 1 & 2 \\
\hline Uluslararası Finansal Raporlama Standartları & 8 & 2 & 0 & 10 & 3 & 4 & 7 \\
\hline Uluslararası Finansal Raporlama Stand.- I & 1 & 0 & 0 & 1 & 0 & 0 & 0 \\
\hline Uluslararası Finansal Raporlama Stand. - II & 1 & 0 & 0 & 1 & 0 & 0 & 0 \\
\hline Uluslararası Muh. ve Fin. Raporlama Standartları & 1 & 0 & 0 & 1 & 2 & 1 & 3 \\
\hline Orta Düzey Muhasebe: UFRS Yaklaşımı I & 0 & 0 & 0 & 0 & 1 & 0 & 1 \\
\hline Orta Düzey Muhasebe: UFRS Yaklaşımı II & 0 & 0 & 0 & 0 & 1 & 0 & 1 \\
\hline TOPLAM & 57 & 4 & 3 & 64 & 21 & 11 & 32 \\
\hline
\end{tabular}

Üniversitelerimizde verilen Genel/Finansal Muhasebe ve Envanter Bilanço gibi çeşitli muhasebe derslerinin içerikleri incelendiğinde bazı fakülte ve bölümlerde bu derslerin muhasebe standartları çerçevesinde anlatıldığ görülmektedir. Ancak bu çalışmada doğrudan TMS/TFRS eğitimine odaklanılan ve ders isimleri içinde Muhasebe ve/veya Finansal Raporlama Standartları olan dersler inceleme kapsamına alınmıştır. 
Devlet ve Vakıf Üniversitelerinin lisans, yüksek lisans ve doktora müfredatlarının incelenmesi sonucunda muhasebe standartları ile ilgili derslerin değişik isimler ile müfredatta yer aldığı tespit edilmiştir. Tablo 9 incelendiğinde üniversitelerimizde lisans düzeyinde TMS/TFRS eğitiminin en çok "Muhasebe Standartları" adıyla verildiği görülmektedir. Muhasebe Standartları adıyla 18'i devlet ve 4'ü vakıf üniversitesinde olmak üzere 22 ders olduğu görülmektedir. TMS/TFRS dersleri arasında "Uluslararası Finansal Raporlama Standartları" dersi ikinci s1rada yer almaktadır. Uluslararası Finansal Raporlama Standartları adıyla 10'u devlet ve 7'si vakıf üniversitesinde olmak üzere 17 ders olduğu görülmektedir. En çok karşılaşılan ders isimleri arasında üçüncü sırayı "Finansal Raporlama Standartları" ve "Uluslararası Muhasebe Standartları" dersleri almaktadır. Finansal Raporlama Standartları adıyla 6'si devlet ve 2'si vakıf üniversitesinde olmak üzere 8 ders, Uluslararası Muhasebe Standartları adıyla 2'si devlet ve 6'sı vakıf üniversitesinde olmak üzere 8 ders olduğu görülmektedir.

Devlet ve vakıf üniversitelerinde yüksek lisans programlarında verilen TMS/TFRS derslerinin isimleri Tablo 10'da verilmiştir.

Devlet üniversitelerinde yüksek lisans programlarında verilen TMS/TFRS derslerine bakıldığında, 6 yüksek lisans programında "Muhasebe Standartları" ve yine 6 yüksek lisans programında "Türkiye Muhasebe Standartları" isimli derslerin ilk sırayı aldıkları görülmektedir. Vakıf üniversitelerinde 11 yüksek lisans programında verilen "Uluslararası Muhasebe Standartları" ilk sırayı alırken 6 yüksek lisans programında verilen "Uluslararası Finansal Raporlama Standartları" ikinci sırada yer almaktadır. Devlet ve vakıf üniversitelerindeki yüksek lisans programlarının geneline bakıldığında, 14 yüksek lisans programında verilen "Uluslararası Muhasebe Standartları" isimli dersin ilk sırada yer aldığı görülmektedir. Devlet ve vakıf üniversitelerinde 9 yüksek lisans programında verilen "Uluslararası Finansal Raporlama Standartları" isimli dersin en çok karşılaşılan ders isimleri arasında ikinci sırayı aldığı, 8 yüksek lisans programında verilen "Muhasebe Standartları" isimli dersin üçüncü sırayı aldığı görülmektedir. 
Tablo 10: Devlet ve Vakıf Üniversitelerinde Yüksek Lisans Programlarında Verilen TMS/TFRS Derslerinin İsimleri

Ders İsimleri

\begin{tabular}{cc} 
Devlet & Vakı \\
\hline In Topl & In
\end{tabular}

\begin{tabular}{|c|c|c|c|c|c|c|}
\hline Ders İsimleri & $\operatorname{Tr}$ & $\mathrm{g}$ & & $\operatorname{Tr}$ & $\mathrm{g}$ & . \\
\hline Muhasebe Standartları & 6 & 0 & 6 & 2 & 0 & 2 \\
\hline Muhasebe Standartları ve Uygulamaları & 5 & 0 & 5 & 0 & 1 & 1 \\
\hline Muhasebe Kuramı, Standartları ve Uygulamaları & 2 & 0 & 2 & 1 & 0 & 1 \\
\hline Muhasebe İlke ve Standartları & 1 & 0 & 1 & 0 & 0 & 0 \\
\hline Meslek Hukuku ve Muhasebe Standartları & 1 & 0 & 1 & 0 & 0 & 0 \\
\hline Muhasebe Standartları ve Sermaye Piyasası & 0 & 0 & 0 & 1 & 0 & 1 \\
\hline Karşılaştırmalı Muhasebe Standartları & 1 & 0 & 1 & 0 & 0 & 0 \\
\hline Türkiye Muhasebe Standartları & 6 & 0 & 6 & 1 & 0 & 1 \\
\hline Türkiye Muh. Standartları/TFRS I & 1 & 0 & 1 & 0 & 0 & 0 \\
\hline Türkiye Muh. Standartları/TFRS II & 1 & 0 & 1 & 0 & 0 & 0 \\
\hline Türkiye Muhasebe Standartları ve Uygulamaları & 0 & 0 & 0 & 1 & 0 & 1 \\
\hline Türkiye Muhasebe /Finansal Raporlama Standartları I & 1 & 0 & 1 & 0 & 0 & 0 \\
\hline Türkiye Muhasebe /Finansal Raporlama Standartları II & 1 & 0 & 1 & 0 & 0 & 0 \\
\hline Türkiye Finansal Raporlama ve Türkiye Muh. Standartları & 1 & 0 & 1 & 0 & 0 & 0 \\
\hline Finansal Raporlama Standartları & 2 & 3 & 5 & 1 & 0 & 1 \\
\hline Finansal Muhasebe ve Raporlama Standartları & 0 & 0 & 0 & 2 & 0 & 2 \\
\hline Finansal Muhasebe Standartları ve Uygulamaları & 0 & 0 & 0 & 1 & 0 & 1 \\
\hline Finansal Raporlama Standartları ve Uygulamaları & 2 & 0 & 2 & 1 & 0 & 1 \\
\hline Uluslararası Muhasebe Standartları & 3 & 0 & 3 & $\begin{array}{l}1 \\
0\end{array}$ & 1 & 11 \\
\hline Uluslararas1 Muhasebe Standartları ve Uygulamalar1 & 2 & 0 & 2 & 0 & 0 & 0 \\
\hline Uluslararası Finansal Raporlama Standartları & 2 & 1 & 3 & 4 & 2 & 6 \\
\hline $\begin{array}{l}\text { Uluslararası Finansal Raporlama Standartları ve Uygulama- } \\
\text { ları }\end{array}$ & 2 & 0 & 2 & 1 & 0 & 1 \\
\hline Uluslararası Muhasebe ve Finansal Raporlama Standartları & 3 & 0 & 3 & 1 & 0 & 1 \\
\hline Muhasebe Denetimi ve Uluslararas1 Muhasebe Standartları & 1 & 0 & 1 & 0 & 0 & 0 \\
\hline Kobi Finansal Raporlama Standartları & 1 & 0 & 1 & 0 & 0 & 0 \\
\hline TOPLAM & $\begin{array}{l}4 \\
5\end{array}$ & 4 & 49 & $\begin{array}{l}2 \\
7\end{array}$ & 4 & 31 \\
\hline
\end{tabular}

Tr:Türkçe, Ing:Ingilizce

Devlet ve vakıf üniversitelerinde doktora programlarında verilen TMS/TFRS derslerinin isimleri Tablo 11'de verilmiştir. 
Tablo 11: Devlet ve Vakıf Üniversitelerinde Doktora Programlarında Verilen TMS/TFRS Derslerinin İsimleri

\begin{tabular}{|c|c|c|c|c|c|c|}
\hline \multirow[b]{2}{*}{ Ders İsimleri } & \multicolumn{3}{|c|}{ Devlet } & \multicolumn{3}{|c|}{ Vakif } \\
\hline & $\operatorname{Tr}$ & İng & Toplam & $\operatorname{Tr}$ & İng & Toplam \\
\hline Muhasebe Standartları & 2 & 0 & 2 & 1 & 0 & 1 \\
\hline Muhasebe Standartları I & 1 & 0 & 1 & 0 & 0 & 0 \\
\hline Muhasebe Standartları II & 1 & 0 & 1 & 0 & 0 & 0 \\
\hline Muhasebe Standartları ve Uygulamaları & 1 & 0 & 1 & 0 & 0 & 0 \\
\hline Türkiye Muhasebe Standartları & 2 & 0 & 2 & 0 & 0 & 0 \\
\hline Muhasebe Standartları ve Raporlama & 1 & 0 & 1 & 0 & 0 & 0 \\
\hline Türkiye Muhasebe Standartları ve Uygulamaları & 0 & 0 & 0 & 2 & 0 & 2 \\
\hline Türkiye Muhasebe /Finansal Raporlama Standartları I & 1 & 0 & 1 & 0 & 0 & 0 \\
\hline Türkiye Muhasebe /Finansal Raporlama Standartları II & 1 & 0 & 1 & 0 & 0 & 0 \\
\hline Muhasebe Kuramı, Standartları ve Uygulamaları & 0 & 0 & 0 & 1 & 0 & 1 \\
\hline Muhasebe ve Fin. Raporlama Standartları Uygulaması & 1 & 0 & 1 & 0 & 0 & 0 \\
\hline Finansal Raporlama Standartları & 1 & 0 & 1 & 0 & 0 & 0 \\
\hline Karşılaştırmalı Fin. Raporlama Stand. ve Uygulamaları & 1 & 0 & 1 & 0 & 0 & 0 \\
\hline Uluslararası Muhasebe Standartları & 10 & 0 & 10 & 2 & 0 & 2 \\
\hline Uluslararası Finansal Raporlama Standartları & 4 & 0 & 4 & 1 & 1 & 2 \\
\hline Uluslararası Muhasebe ve Fin. Raporlama Standartları & 1 & 0 & 1 & 0 & 0 & 0 \\
\hline Uluslararası Muhasebe ve Raporlama Standartları & 1 & 0 & 1 & 3 & 1 & 4 \\
\hline TOPLAM & 29 & $\mathbf{0}$ & 29 & 10 & 2 & 12 \\
\hline
\end{tabular}

Tr:Türkçe, İng:Ingilizce

Devlet üniversitelerinde doktora programlarında verilen TMS/TFRS derslerine bakıldığında, 10 doktora programında "Uluslararası Muhasebe Standartları" isimli dersin ilk sırayı aldığı görülmektedir. Vakıf üniversitelerinde 4 doktora programında verilen "Uluslararası Muhasebe ve Raporlama Standartları" ilk s1rayı almaktadır. Devlet ve vakıf üniversitelerindeki doktora programlarının geneline bakıldığında, 12 doktora programında verilen "Uluslararası Muhasebe Standartları" isimli dersin ilk sırada yer aldığı görülmektedir. Devlet ve vakıf üniversitelerinde 6 doktora programında verilen "Uluslararas1 Finansal Raporlama Standartları" isimli dersin en çok karşılaşılan ders isimleri arasında ikinci sırayı aldığı, 5 doktora programında verilen "Uluslararası Muhasebe ve Raporlama Standartları" isimli dersin üçüncü sırayı aldığı görülmektedir.

Bazı üniversitelerde muhasebe ve finansal raporlama standartlarına ilişkin olarak verilen derslerin hem lisans hem de lisansüstü programlarda aynı isimle verildiği görülmektedir. Araştırmada sekiz üniversitede lisans ve lisansüstü programlarda aynı isimli ders olduğu belirlenmiştir. Bu üniversitelerden üçünde İşletme lisans ve yüksek lisans programlarında Muhasebe Standartları adıyla ders verildiği tespit edilmiş ancak bir üniversitesinde lisans, diğer iki üniversitede ise 
yükssek lisans ders içeriğine ulaşılamadığından karşılaştırma yapılamamıştır. Bir üniversitede İșletme lisans ve yüksek lisans programlarında Finansal Raporlama Standartları isimli dersin aynı içerik ile verildiği görülmüştür. Bir başka üniversitede ise Muhasebe ve Finansman yüksek lisans ve doktora programlarında Türkiye Muhasebe/Finansal Raporlama Standartları I ve II isimli dersler olduğu tespit edilmiş ancak ders içeriklerine ulaşılamadığından içerik karşılaştırması yapılamamıştır. Hem yüksek lisans hem de doktora programında Muhasebe Standartları ve Uygulamaları adıyla ders verilen bir üniversitede ders içeriklerinin kısmen aynı olduğu, Uluslararası Muhasebe Standartları adıyla yüksek lisans ve doktora programlarında ders verilen iki üniversitede ise içeriklerin tamamen aynı olduğu görülmüştür. Lisans, yüksek lisans veya doktora programlarında TMS/TFRS'lere ilişkin derslerin aynı isim ve içerikle verilmemesi, farklı düzeylerde farklı isim ve içerikle verilmesi ve lisansüstü düzeyde verilen derslerin lisans düzeyinde verilen dersleri tamamlayıcı nitelikte olması daha uygun olacaktır.

\section{E. TMS/TFRS DERSLERİIIN TÜRÜ (SEÇIMLIIK/ZORUNLU) VE DERS SAATLERI}

Muhasebe eğitimi verilen lisans bölümlerinde verilen TMS/TFRS dersleri zorunlu/seçmeli olma durumları ve ders saatleri açısından incelenmiş ve tablo 12'de gösterilmiştir.

Tablo 12: Lisans Düzeyinde Verilen TMS/TFRS Derslerinin Zorunlu/Seçmeli Olma Durumu

\begin{tabular}{lcccccc}
\hline Lisans & \multicolumn{3}{c}{ Devlet Üniversiteleri } & \multicolumn{3}{c}{ Vakıf Üniversiteleri } \\
\cline { 2 - 7 } Ders Saati & Zorunlu & Seçmeli & Toplam & Zorunlu & Seçmeli & Toplam \\
\hline 2 Saat & 1 & 2 & 3 & 0 & 0 & 0 \\
3 Saat & 13 & 48 & 61 & 7 & 25 & 32 \\
\hline Toplam & $\mathbf{1 4}$ & $\mathbf{5 0}$ & $\mathbf{6 4}$ & $\mathbf{7}$ & $\mathbf{2 5}$ & $\mathbf{3 2}$ \\
\hline
\end{tabular}

Tablo 12 incelendiğinde vakıf üniversitelerindeki lisans programlarında TMS/TFRS derslerinin tamamının 3 saat olduğu görülürken devlet üniversitelerinde 3 dersin 2 saat 61 dersin ise 3 saat olarak müfredatlarda yer aldığ görülmektedir. Derslerin zorunlu/seçimlik olma durumu incelendiğinde devlet üniversitelerinde 14 zorunlu 50 seçmeli, vakıf üniversitelerinde ise 7 ders zorunlu 25 ders seçmeli olarak müfredatta gösterilmiştir.

Muhasebe eğitimi verilen yüksek lisans programlarında verilen TMS/TFRS derslerinin zorunlu/seçmeli olma durumları ve ders saatleri Tablo 13'te gösterilmiştir. Tablodan da görüleceği gibi devlet üniversitelerinde yüksek lisans programlarında verilen toplam 49 dersin 6'sı zorunlu 43'ü seçmelidir. Vakıf üniversitelerinde ise toplam 31 dersin 11 'i zorunluyken 20'si seçmeli olarak müfredatlarda yer almaktadir.

Tablo 13: Yüksek Lisans Düzeyinde Verilen TMS/TFRS Derslerinin Zorunlu/ Seçmeli Olma Durumu

\begin{tabular}{lcccccc}
\hline Y.Lisans & \multicolumn{3}{c}{ Devlet Üniversiteleri } & \multicolumn{3}{c}{ Vakıf Üniversiteleri } \\
\cline { 2 - 6 } Ders Saati & Zorunlu & Seçmeli & Toplam & Zorunlu & Seçmeli & Toplam \\
\hline 3 Saat & 6 & 43 & $\mathbf{4 9}$ & 11 & 20 & $\mathbf{3 1}$ \\
\hline
\end{tabular}


Muhasebe eğitimi verilen doktora programlarında verilen TMS/TFRS derslerinin zorunlu/seçmeli olma durumları ve ders saatleri Tablo 14'te gösterilmiștir. Tablo incelendiğinde, devlet üniversitelerinde doktora programlarında verilen toplam 28 dersin 3'ü zorunlu 25'i seçmelidir. Vakıf üniversitelerinde ise toplam 12 dersin 2'si zorunluyken 10'u seçmeli olarak müfredatlarda yer almaktadır.

Tablo 14: Doktora Düzeyinde Verilen TMS/TFRS Derslerinin Zorunlu/Seçmeli Olma Durumu

\begin{tabular}{|c|c|c|c|c|c|c|}
\hline \multirow{2}{*}{$\begin{array}{l}\text { Doktora } \\
\text { Ders Saati }\end{array}$} & \multicolumn{3}{|c|}{ Devlet Üniversiteleri } & \multicolumn{3}{|c|}{ Vakıf Üniversiteleri } \\
\hline & Zorunlu & Seçmeli & Toplam & Zorunlu & Seçmeli & Toplam \\
\hline 3 Saat & 3 & 25 & 28 & 2 & 10 & 12 \\
\hline . & $\begin{array}{l}\text { UHAS } \\
\text { ERİK }\end{array}$ & $\mathbf{S}$ & El & INA & İLİŞK & DERS \\
\hline
\end{tabular}

Çalışmanın bu aşamasında devlet ve vakıf üniversitelerinde verilen derslerin müfredatları ders içerikleri açısından incelenmiș olup içeriklerde ağırlıklı olarak hangi TMS/TFRS'lere yer verildiği tespit edilmiştir.

Devlet üniversitelerinde lisans programlarında, verilmekte olan toplam 64 dersten 39'unun (\%61) içeriğine ulaşılmıştır. Vakıf üniversitelerinde ise 32 dersten 20 'sinin $(\% 62,5)$ içeriğine ulaşılmıştır. Devlet üniversitelerinde yüksek lisans programlarında verilen 49 dersten 18 (\%37) dersin içeriğine ulaşılmıştır. Vakıf üniversitelerinde ise 31 dersten 23'ünün (\%74) içeriğine ulaşılmıștır. Devlet üniversitelerinde doktora programlarında 28 dersten 14'ünün (\%50) içeriğine ulaşılmıştır. Vakıf üniversitelerinde ise 12 dersten 9 (\%75) dersin içeriğine ulaşılmıştır. Lisans programlarında ders içeriğine ulaşma oranı devlet üniversitelerinde daha yüksek iken, yüksek lisans ve doktora programlarında ders içeriğine ulaşma oranının Vakıf üniversitelerinde daha yüksek olduğu görülmektedir.

Lisans, yüksek lisans ve doktora düzeyinde içeriğine ulaşılan derslerde TMS/TFRS'lerin ders içeriğinde yer alma durumları incelendiğinde Tablo 15 'deki sonuçlara ulaşılmaktadır. 
Tablo 15: Devlet ve Vakıf Üniversitelerinde TMS/TFRS Ders İçerikleri

\begin{tabular}{|c|c|c|c|c|c|c|}
\hline \multirow[b]{2}{*}{ TMS/TFRS } & \multicolumn{3}{|c|}{ Devlet Üniversiteleri } & \multicolumn{3}{|c|}{ Vakıf Üniversiteleri } \\
\hline & Lisans & Y.Lisans & Doktora & Lisans & Y.Lisans & Doktora \\
\hline $\begin{array}{l}\text { Finansal Raporlamaya İli- } \\
\text { şin Kav. Çerçeve }\end{array}$ & 22 & 12 & 10 & 11 & 7 & 5 \\
\hline TMS-1 & 22 & 13 & 8 & 11 & 6 & 5 \\
\hline TMS-2 & 22 & 10 & 8 & 11 & 7 & 5 \\
\hline TMS-7 & 22 & 8 & 8 & 10 & 5 & 4 \\
\hline TMS-8 & 10 & 5 & 7 & 5 & 4 & 4 \\
\hline TMS-10 & 6 & 4 & 8 & 1 & 0 & 4 \\
\hline TMS-11 & 4 & 6 & 3 & 5 & 1 & 0 \\
\hline TMS-12 & 12 & 7 & 7 & 6 & 5 & 1 \\
\hline TMS-16 & 20 & 10 & 7 & 11 & 6 & 4 \\
\hline TMS-17 & 6 & 4 & 4 & 3 & 2 & 4 \\
\hline TMS-18 & 20 & 8 & 9 & 10 & 5 & 4 \\
\hline TMS-19 & 1 & 0 & 4 & 0 & 2 & 1 \\
\hline TMS-20 & 1 & 1 & 1 & 2 & 1 & 0 \\
\hline TMS-21 & 10 & 5 & 6 & 6 & 3 & 0 \\
\hline TMS-23 & 17 & 9 & 6 & 8 & 2 & 1 \\
\hline TMS-24 & 6 & 0 & 4 & 2 & 0 & 0 \\
\hline TMS-26 & 0 & 0 & 0 & 0 & 2 & 0 \\
\hline TMS-27 & 2 & 5 & 4 & 1 & 2 & 0 \\
\hline TMS-28 & 0 & 2 & 5 & 1 & 2 & 0 \\
\hline TMS-29 & 0 & 0 & 0 & 1 & 0 & 0 \\
\hline TMS-32 & 5 & 1 & 5 & 1 & 1 & 0 \\
\hline TMS-33 & 2 & 1 & 3 & 1 & 1 & 0 \\
\hline TMS-34 & 1 & 0 & 3 & 0 & 1 & 0 \\
\hline TMS-36 & 14 & 12 & 10 & 8 & 5 & 4 \\
\hline TMS-37 & 8 & 5 & 8 & 6 & 5 & 3 \\
\hline TMS-38 & 13 & 7 & 9 & 6 & 3 & 0 \\
\hline TMS-39 & 15 & 2 & 5 & 2 & 0 & 1 \\
\hline TMS-40 & 2 & 6 & 4 & 2 & 3 & 0 \\
\hline TMS-41 & 2 & 2 & 1 & 0 & 1 & 0 \\
\hline
\end{tabular}


Tablo 15: (Devami)

\begin{tabular}{|c|c|c|c|c|c|c|}
\hline TFRS-1 & 9 & 2 & 4 & 2 & 1 & 1 \\
\hline TFRS-2 & 2 & 0 & 1 & 0 & 0 & 0 \\
\hline TFRS-3 & 5 & 5 & 4 & 0 & 0 & 0 \\
\hline TFRS 4 & 1 & 0 & 1 & 0 & 0 & 0 \\
\hline TFRS-5 & 6 & 2 & 6 & 1 & 0 & 0 \\
\hline TFRS-6 & 1 & 1 & 1 & 0 & 0 & 0 \\
\hline TFRS-7 & 8 & 0 & 2 & 1 & 1 & 1 \\
\hline TFRS-8 & 3 & 0 & 2 & 1 & 0 & 0 \\
\hline TFRS-9 & 1 & 1 & 4 & 1 & 0 & 1 \\
\hline TFRS-10 & 0 & 0 & 1 & 0 & 0 & 0 \\
\hline TFRS-11 & 0 & 0 & 0 & 0 & 0 & 0 \\
\hline TFRS-12 & 0 & 0 & 0 & 0 & 0 & 0 \\
\hline TFRS-13 & 1 & 0 & 1 & 0 & 0 & 0 \\
\hline TFRS 14 & 1 & 0 & 0 & 0 & 0 & 0 \\
\hline
\end{tabular}

Tablo 15 'te lisans, yüksek lisans ve doktora programlarında içeriğine ulaş1lan derslerde TMS/TFRS'lerin ders içeriklerinde bulunma sayıları verilmiştir. Buna göre devlet üniversitelerinde lisans programlarında en çok yer verilen TMS/TFRS'ler arasında ilk sırayı 22 ders içeriğinde rastlanılan Finansal Raporlamaya İliş̧kin Kavramsal Çerçeve, TMS-1, TMS-2 ve TMS-7 standartları almaktadır. TMS-16 ve TMS-18'e 20 ders içeriğinde, TMS-23'e 17 ders içeriğinde, TMS39'a 15 ders içeriğinde, TMS-36'ya 14 ders içeriğinde, TMS-38'e 13 ders içeriğinde, TMS-8 ve TMS-21'e ise 10 ders içeriğinde rastlanmıştır. Vakıf üniversitelerinde lisans programlarında en çok yer verilen TMS/TFRS'ler arasında ilk s1ray1 11 ders içeriğinde rastlanılan Finansal Raporlamaya İlişkin Kavramsal Çerçeve, TMS-1, TMS-2 ve TMS-16 standartları, ikinci sırayı 10 dersin içeriğinde görülen TMS-7, TMS-18 standartları, üçüncü sırayı ise 8 ders içeriğinde görülen TMS-23 ve TMS-36 standartları almaktadır.

Yüksek lisans programlarında TMS/TFRS'lerin bulunma durumuna bakıld1ğında, devlet üniversitelerinde 13 ders içeriğinde görülen Finansal Raporlamaya İlişkin Kavramsal Çerçeve ve TMS-1 ilk sırayı, 12 ders içeriğinde bulunan TMS36 ikinci sırayı ve 10 ders içeriğinde görülen TMS-2 ve TMS-16 standartları üçüncü sırayı almaktadır. Vakıf üniversitelerinde 7 ders içeriğinde görülen Finansal Raporlamaya İlişkin Kavramsal Çerçeve ve TMS-2 ilk sırayı, 6 ders içeriğinde bulunan TMS-1 ve TMS-16 ikinci sırayı ve 5 ders içeriğinde görülen TMS-7, TMS-18, TMS-36 ve TMS-37 standartları üçüncü sırayı almaktadır.

Doktora programlarında TMS/TFRS'lerin ders içeriklerinde bulunma durumuna bakıldığında, devlet üniversitelerinde ilk sırayı 10 ders içeriğinde görülen Finansal Raporlamaya İlişkin Kavramsal Çerçeve ve TMS-36 standardı almaktadır. Ders içeriklerinde en çok yer verilen standartlar arasında ikinci sırayı 9 ders içeriğinde bulunan TMS-18 ve TMS-38 standartları, üçüncü sırayı ise 8 ders içe- 
riğinde görülen TMS-1, TMS-2, TMS-7, TMS-10 ve TMS-37 standartları almaktadır. Vakıf üniversitelerinde 5 ders içeriğinde görülen Finansal Raporlamaya İlişkin Kavramsal Çerçeve, TMS-1, TMS-2 ve TMS-7 ilk sırayı, 4 ders içeriğinde bulunan TMS-7, TMS-8, TMS-10, TMS-16, TMS-17, TMS-18 ve TMS-36 ikinci sırayı almaktadır. Vakıf üniversitelerinde doktora programlarında en çok yer alan standartlar arasında üçüncü sırayı 3 ders içeriğinde görülen TMS-37 almaktadır.

\section{SONUÇ}

Bu çalışma, Türkiye'deki devlet ve vakıf üniversitelerinin lisans, yüksek lisans ve doktora düzeyinde muhasebe eğitimi verilen fakülte, yüksekokul ve enstitülerinde TMS/TFRS eğitiminin hangi düzeyde verildiğini araştırmak amacıyla yapılmıştır. Araştırmada ulaşılan sonuçlar lisans, yüksek lisans ve doktora programları olmak üzere sırasıyla üç bölümde verilmiştir.

1-Türkiye'de Haziran 2016 tarihi itibariyle Yükseköğretim Kurulu'na bağl1 olarak faaliyet gösteren 109'u devlet ve 76'sı vakıf üniversitesi olmak üzere toplam 185 üniversite bulunmaktadır. Devlet üniversitelerinde 147, vakıf üniversitelerinde 72 olmak üzere toplam 219 fakülte ve yüksekokulda muhasebe eğitimi verilmektedir. Muhasebe eğitimi verilen fakülteler arasında 92'si devlet ve 32'si vakıf üniversitelerinde olmak üzere toplam 124 adet fakülte ile İ̈BF'ler ilk sırayı almaktadırlar.

Çalı̧̧mada lisans düzeyinde muhasebe eğitimi verilen fakülte ve yüksekokullarda işletme bölümleri ile muhasebe bölümleri (Muhasebe, Muhasebe ve Denetim, Muhasebe ve Finansal Yönetim, Muhasebe Bilgi Sistemleri) araştırma kapsamına dahil edilmiştir. İşletme bölümü sayısı devlet üniversitelerinde 126, vakıf üniversitelerinde ise 72 'dir. Devlet üniversiteleri bünyesindeki işletme bölümlerinin 107'sinde Türkçe, 17'sinde İngilizce, 2'sinde ise Almanca eğitim verilmektedir. Vakıf üniversiteleri bünyesindeki işletme bölümlerinin 33'ünde Türkçe eğitim verilirken 39'unda ise İngilizce eğitim verilmektedir. Devlet üniversitelerinde bulunan 8 muhasebe lisans programının 7'sinin UBYO'da, 1'inin de Uygulamalı Teknoloji ve İşletmecilik Yüksekokulunda bulunduğu görülmüsstür. Vakıf üniversitelerinde bulunan 10 muhasebe programının 6'sının fakültelerde, 4'ünün UBYO'larda bulunduğu görülmektedir.

Lisans düzeyinde TMS/TFRS eğitiminin devlet üniversitelerinde 48, vakıf üniversitelerinde ise 32 bölümde verildiği görülmüsstür. Devlet üniversitelerinde 126 işletme ve 8 muhasebe bölümü olmak üzere toplam 134 bölümün \%36'sında, vakıf üniversitelerinde ise 72 işletme ve 10 muhasebe bölümü olmak üzere 82 bölümün \%39'unde muhasebe standartları dersi verilmektedir.

Üniversitelerimizde lisans düzeyinde TMS/TFRS eğitiminin en çok "Muhasebe Standartları" adıyla verildiği görülmektedir. En çok karşılaşılan ders isimleri arasında "Uluslararası Finansal Raporlama Standartları" dersi ikinci sırada, "Finansal Raporlama Standartları" ve "Uluslararası Muhasebe Standartları" dersleri üçüncü sırada yer almaktadır.

Lisans düzeyinde verilen TMS/TFRS derslerinden, vakıf üniversitelerindeki derslerin tamamının 3 saat olduğu görülürken devlet üniversitelerinde 3 dersin 2 saat 61 dersin ise 3 saat olarak müfredatlarda yer aldığ görülmektedir. Derslerin 
zorunlu/seçimlik olma durumu incelendiğinde devlet üniversitelerinde 14 ders zorunlu 50 ders seçmeli, vakıf üniversitelerinde ise 7 ders zorunlu 25 ders seçmeli olarak müfredatlarda gösterilmiştir.

2- Ülkemizdeki devlet üniversitelerinde 75 İşletme yüksek lisans programı, 9 Muhasebe-Finansman yüksek lisans program1, 4 Muhasebe ve 3 Muhasebe-Denetim yüksek lisans programı olmak üzere 91 yüksek lisans programında muhasebe eğitimi verilmektedir. Vakıf üniversitelerinde ise 68 işletme, 5 muhasebefinansman, 4 muhasebe ve 9 muhasebe-denetim olmak üzere 86 yüksek lisans programı bulunmaktadır. Devlet üniversitelerde 46, vakıf üniversitelerinde ise 28 Yüksek Lisans programında TMS/TFRS dersi verildiği görülmüştür. Buna göre devlet üniversitelerindeki yüksek lisans programlarının \%51'inde, vakıf üniversitelerindeki yüksek lisans programlarının \%33'ünde TMS/TFRS dersinin müfredatlarda yer aldığı tespit edilmiştir.

Devlet ve vakıf üniversitelerindeki yüksek lisans programlarında en çok karşılaşılan TMS/TFRS ders isimlerine bakıldığında, "Uluslararası Muhasebe Standartları" isimli dersin ilk sirada, "Uluslararası Finansal Raporlama Standartları" isimli dersin ikinci sırada ve "Muhasebe Standartları" isimli dersin üçüncü sırada yer aldığı görülmektedir.

Muhasebe eğitimi verilen yüksek lisans programlarında verilen TMS/TFRS derslerinin tamamı 3 saat olarak verilmektedir. Devlet üniversitelerinde verilen toplam 49 dersin 6'sı zorunlu 43'ü seçmelidir. Vakıf üniversitelerinde ise toplam 31 dersin 11'i zorunluyken 20'si seçmeli olarak müfredatlarda yer almaktadır.

3- Türkiye'de devlet üniversitelerinde 58 İşletme, 5 Muhasebe-Finansman ve 1 Muhasebe doktora programı bulunmaktadır. Vakıf üniversitelerinde ise 39 işletme, 2 muhasebe-finansman, 5 Muhasebe-Denetim doktora programı olduğu tesit edilmiştir. Devlet üniversitelerinde 23'ü işletme, 3'ü Muhasebe-Finansman olmak üzere toplam 26 doktora programında TMS/TFRS ile ilgili derslerin müfredatta olduğu görülmektedir. Vakıf üniversitelerinde ise 10 İşletme, 2 MuhasebeFinansman ve 4 Muhasebe-Denetim olmak üzere 16 doktora programında TMS/TFRS dersinin müfredatlarda olduğu tespit edilmiştir. Devlet üniversitelerinde muhasebe eğitimi verilen 64 Doktora programının \%41'inde, vakıf üniversitelerinde ise muhasebe eğitimi verilen 46 Doktora programının \%35'inde TMS/TFRS dersinin müfredatlarda yer aldığı tespit edilmiştir.

Devlet ve vakıf üniversitelerindeki doktora programlarında verilen TMS/TFRS ders isimlerine bakıldığında en çok karşılaşılan ders isimlerinin sırasiyla "Uluslararası Muhasebe Standartları", "Uluslararası Finansal Raporlama Standartları" ve "Uluslararası Muhasebe ve Raporlama Standartları" isimli dersler olduğu görülmüştür.

Muhasebe eğitimi verilen doktora programlarında verilen TMS/TFRS derslerinin tamamı 3 saat olarak verilmektedir. Devlet üniversitelerinde doktora programlarında verilen toplam 28 dersin 3'ü zorunlu 25'i seçmelidir. Vakıf üniversitelerinde ise toplam 12 dersin 2'si zorunluyken 10'u seçmeli olarak müfredatlarda yer almaktadır 
Lisans, yüksek lisans ve doktora programlarında verilen TMS/TFRS derslerinin içerikleri incelendiğinde, içeriğine ulaşılan derslerde bazı TMS/TFRS'lere ders içeriklerinde yer verilirken bazılarına ya hiç yer verilmediği ya da çok az yer verildiği görülmüştür. İçeriğine ulaşılan derslerin mevcut içerikleriyle TMS/TFRS tam setini karşılamadığ tespit edilmiştir.

Araştırma sonuçları, ülkemizdeki üniversitelerin muhasebe eğitimi verilen lisans, yüksek lisans ve doktora programlarında TMS/TFRS eğitimine gereken önemin henüz verilmediğini göstermektedir. Muhasebe ve Finansal Raporlama Standartları konusunun uzun zamandır gündemde olmasına rağmen üniversitelerde TMS/TFRS setinin eğitim planlarına dahil edilmemesinin başlıca nedenleri olarak; standartları uygulayacak olan işletme sayısının ülkemizdeki toplam işletme sayısına oranla çok az olması, bazı standartların karmaşık bir yapıya sahip olması nedeniyle yeterince anlaşılamaması, standartların uygulanması konusundaki belirsizlik ve bazı öğretim elemanlarının konuya ilgisizliği ve müfredat değişikliğine karşı olan tutumları sayılabilir.

Üniversitelerde lisans ve lisansüstü düzeylerde verilen TMS/TFRS eğitiminin istenilen niteliğe ulaşması için öncelikle THP'nin standartlara uygun şekilde güncellemesi ve bu doğrultuda uygulamada görülen farkl11ıkların ortadan kaldırılması verilen eğitimin kalitesini arttırmak için gereklidir. Gerek uygulayıcı gerekse akademisyen olarak muhasebe mesleğinin çeşitli kademelerinde görev yapan elemanlar yetiştiren üniversitelerin hem lisans hem de lisansüstü programlarında verilen muhasebe eğitiminde, ders müfredatlarının TMS/TFRS eğitimini içerecek şekilde gözden geçirilerek yeniden yapılandırılması gerekmektedir. 


\section{KAYNAKÇA}

AGOGLIA, Christopher P.; Timothy S. DOUPNIK and George T. TSAKUMIS; (2011), "Principles-based versus Rules-based Accounting Standards: The Influence of Standard Precision and Audit Committee Strength on Financial Reporting Decisions", The Accounting Review, 86 (3), pp.747-767.

AKDOĞAN, Nalan; (2007), “Türkiye Muhasebe/Finansal Raporlama Standartlarının Uygulanma Süreci: Sorunlar, Çözüm Önerileri”, Mali Çözüm, 80, ss.101-117.

AKGÜN, Ali İ.; (2012), "Muhasebenin Uluslararası Harmonizasyonu ve İlke Bazlı Muhasebe Anlayışına Yöneliş", Yönetim ve Ekonomi, 19 (2), ss.116.

AKTÜRK, Ahmet; (2014), "Muhasebe Meslek Mensuplarının Muhasebe Standartlarına Uyumu Sürecinde Eğitim Faktörü Üzerine Antalya İlinde Bir Araştırma", Mali Çözüm, 122, ss.63-84.

BAŞPINAR, Ahmet; (2004), “Türkiye'de ve Dünyada Muhasebe Standartlarının Oluşumuna Genel Bir Bakış", Maliye Dergisi, 146, ss.42-57.

CARVALHO, Nelson L. and Bruno M. SALOTTI; (2013), "Adoption of IFRS in Brazil and the Consequences to Accounting Education", Issues in Accounting Education, 28 (2), pp. 235-242.

ÇANKAYA, Fikret ve Oğuzhan HATIPOĞLU; (2011), “Türkiye'de Uluslararası Muhasebe Standartları'nın Uygulanabilirliğini Etkileyen Faktörlerin Meslek Mensuplarınca Değerlendirilmesine Yönelik Bir Araştırma", Uluslararası İktisadi ve İdari İncelemeler Dergisi, 4 (7), ss. 61-89.

DAŞTAN, Abdulkerim ve Uğur BELLİKLİ; (2016), "Muhasebe ve Finansal Raporlama Standartları Eğitiminde İdeali Arayış: Türkiye'de Bir Araştırma”, iç. Dursun ARIKBOĞA (Ed.), Değişen Dünyada Finansal Raporlama: İdeali Arayış ve Muhasebe Eğitimi, 35.Türkiye Muhasebe Eğitimi Sempozyumu, 27 Nisan-1 Mayıs, Antalya, ss.45-72.

DURAK, Gündoğan; (2012), "Uluslararası Muhasebe Standartlarının Kavramsal Çerçevesi”, Vergi Dünyası, 368, ss.38-45,

DURER, Salih; Halil Emre AKBAŞ ve Emin ZEYTINOĞLU; (2016), "Uluslararası Finansal Raporlama Standartları ve Türkiye'de Muhasebe Eğitimi: Muhasebe Eğitimi Veren Akademisyenlerin Görüşleri Üzerine Bir İnceleme", ", iç. Dursun ARIKBOĞA (Ed.), Değişen Dünyada Finansal Raporlama: İdeali Arayış ve Muhasebe Eğitimi, 35.Türkiye Muhasebe Eğitimi Sempozyumu, 27 Nisan-1 Mayıs, Antalya, ss.125-148. GÖKÇEN, Gürbüz; Başak ATAMAN ve Cemal ÇAKICI; (2011), Türkiye Finansal Raporlama Standartları Uygulamaları, İstanbul: Türkmen Kitabevi. 
GÖKÇEN, Gürbüz; Başak ATAMAN; Yasin CEBECİ ve Hakan CAVLAK; (2015), "Türkiye'deki Devlet Üniversitelerinin Lisans Programlarındaki Muhasebe Standartları Eğitimi Üzerine Bir Araştırma", Marmara Üniversitesi Öneri Dergisi, 11 (44), ss. 121-145.

Gümrük ve Ticaret Bakanlığı; (2017), İnternet Adresi: http://icticaret. gtb.gov.tr/data/5315a212487c8e0fd48d2262/\%C5\%9 Eirket\%20\%C4\% B0statistikleri\%20B\%C3\%BClteni\%20(Haziran-2014).pdf, Erişim Tarihi: 02.10.2017.

GÜCENME GENÇOĞLU, Ümit;(2007), Türkiye Muhasebe Standartları ve Uygulamalar, İstanbul: Türkmen Kitabevi.

HACIHASANOĞLU, Tansel; Nevran KARACA ve Şuayip D. DEMIRCI;;(2012), “KOBI'ler İçin TFRS'nin Getirdiği Yeniklikler ve Uygulanabilirliği Üzerine Ankara İlinde Bir Araştırma", 2.Uluslararası Türk Dünyasında UFRS Sempozyumu, 16-17 Haziran, Trabzon, ss.163-189.

HATUNOĞLU, Zeynep ve Mustafa KILLI; (2014), "Hastane İşletmelerinin İstihdam Ettikleri Muhasebe Elemanlarında Aradıkları Nitelikler ve Muhasebe Eğitiminden Beklentileri: Kahramanmaraş, Gaziantep ve Osmaniye İllerinde Bir Alan Çalışması", Niğde Üniversitesi İïBF Dergisi, 7 (1), ss. 228-242.

İBİş, Cemal ve Serdar ÖZKAN; (2006), "Uluslararası Finansal Raporlama Standartları (UFRS)'na Genel Bakış", Mali Çözüm, 74, ss. 25-43.

JACKLING, Beverley, Paul A. DE LANGE and Riccardo, NATOLI; (2013), "Transitioning to IFRS in Australian Classrooms: Impact on Teaching Approaches", Issues in Accounting Education, 28 (2), pp. 263-275.

KARCIOĞLU, Reşat ve Şakir DIZMAN; (2016), “Türkiye'de TMS-TFRS

Kapsamında Verilen Muhasebe Eğitiminin Kalite Standartları Açısında Yeterliliğì", iç. Dursun ARIKBOĞA (Ed.), Değișen Dünyada Finansal Raporlama: İdeali Arayış ve Muhasebe Eğitimi, 35.Türkiye Muhasebe Eğitimi Sempozyumu, 27 Nisan-1 May1s, Antalya, ss.213-232.

KIYMETLİ ŞEN, İlker; Serkan TERZİ ve Begüm ÖKTEM; (2016), "Uluslararası Finansal Raporlama Standartlarına Geçişte ve Uygulamada Karşılaşılabilecek Güçlükler: Meslek Mensupları Üzerinde Bir Araştırma", iç. Dursun ARIKBOĞA (Ed.), Değişen Dünyada Finansal Raporlama: İdeali Arayış ve Muhasebe Eğitimi, 35.Türkiye Muhasebe Eğitimi Sempozyumu, 27 Nisan-1 Mayıs, Antalya, ss. 25-42.

KGK (Kamu Gözetimi Muhasebe ve Denetim Standartları Kurumu); (2016), İnternet Adresi: http://www.kgk.gov.tr/contents/files/Pdf/KGK_ Brosur.pdf, Erişim Tarihi:15.05.2016.

KGK (Kamu Gözetimi Muhasebe ve Denetim Standartları Kurumu); (2017a), İnternetAdresi:http://www.kgk.gov.tr/Portalv2Uploads/files/ DynamicContentFiles/T\%C3\%BCrkiye\%20Muhasebe\%20Standartlar\% C4\%B1/Kurul\%20Kararlar\%C4\%B1/TMSTFRS\%20lerin\%20Uygulam a\%20Kapsam\%C4\%B1na\%20\%C4\%B0li\%C5\%9Fkin\%20Kurul\%20K aralar\%C4\%B1.pdf, Erişim Tarihi:10.09.2017. 
KGK (Kamu Gözetimi Muhasebe ve Denetim Standartları Kurumu); (2017b) İnternet Adresi: http://kgk.gov.tr/ContentAssingmentDetail/ 1350/Bu\%CC\%88yu\%CC\%88k-ve-Orta-Boy-I\%CC\%87s\%CC\%A71 etmeler-I\%CC\%87c\%CC\%A7in-Finansal-Raporlama-Standard\%C4\% B1, Erişim Tarihi:02.10.2017.

KOÇYIĞİT, Seyhan ve Şükran GÜNGÖR TANÇ; (2016), "Türkiye'deki Üniversitelerde Lisanüstü Eğitim Programlarında Yer Alan Muhasebe Standartları Dersleri Üzerine Bir Araştırma”, iç. Dursun ARIKBOĞA (Ed.), Değişen Dünyada Finansal Raporlama: İdeali Arayış ve Muhasebe Eğitimi, 35.Türkiye Muhasebe Eğitimi Sempozyumu, 27 Nisan-1 Mays, Antalya, ss.149-176.

NOBES, Christopher and Robert PARKER;(2008), Comparative International Accounting, Tenth Edition, Prentice Hall, Harlow, England.

TAKIM, Abdullah; (2010), "Gelişmekte Olan Ülkelere Yönelik Yabancı Sermaye Hareketlerinin Makroekonomik Etkileri”, Bartın Üniversitesi İïBF Dergisi, 1, ss. 39-59.

TÜRMOB; (2017), "Büyük ve Orta Boy İşletmeler İçin Finansal Raporlama Standard1 (Bobi Frs) Uygulamas1 1 Ocak 2018'de Bașliyor, Mevzuat Sirküleri”, İnternet Adresi: http://www.turmob.org.tr/ TurmobWeb/ EKutuphane/EKIcerikDetay.aspx?enc=lEkNSf+wNjLKtkG+BZKcV1X s5Phxt2PNuHfqC21VVWcIUwGHp7OFQcioUVhSXQoJFnknJQ5Xit0 =, Erişim Tarihi:19.09.2017.

USTA, Aydın; (2012), "Sorunsaldan Sonuçlara Bilimsel Araştırma Süreci: Bir Araştırma Raporu Model Örneği”, ODÜ Sosyal Bilimler Enstitüsü Sosyal Bilimler Araştırmaları Dergisi, 3(5), ss.135-161.

Yüksek Öğretim Kurumu; (2016), İnternet Adresi: https://istatistik.yok.gov.tr, Erişim Tarihi: 28.04.2016. 